Supporting Information for:

\title{
A Charged Coordination Cage-Based Porous Salt
}

Aeri J. Gosselin, Gerald E. Decker, Alexandra M. Antonio, Gregory R. Lorzing, Glenn P. A. Yap, and Eric D. Bloch*

Department of Chemistry and Biochemistry, University of Delaware, Newark, Delaware 19716, United States 
Detailed Experimental Procedures

List of Contents

Thermogravimetric Analysis

S3-S8

IR Spectroscopy

XPS

S 10

SEM

$\mathrm{S} 10$

EDX

$\mathrm{S} 11$

Gas Adsorption Analysis

$\mathrm{S} 11$

NMR Digestion

$\mathrm{S} 11-\mathrm{S} 12$

Mass Spectrometry

S13-S15

PXRD

S16-S17

Metal-Organic Cage SEM

S18-S19

Porous Salt NMR Digestions

$\mathrm{S} 20$

Single-Crystal X-ray Crystallography

S21-S23

Table of Surface Areas for Relevant Cages

S24

S25

References

S25

List of compound names:

1: $\mathrm{Li}_{24}\left[\mathrm{Cu}_{24}\left(\mathrm{SO}_{3} \text {-bdc }\right)_{24}\right] / \mathrm{Cu} \_\mathrm{Li}$

2: $\mathrm{TEA}_{24}\left[\mathrm{Cu}_{24}\left(\mathrm{SO}_{3} \text {-bdc }\right)_{24}\right] / \mathrm{Cu}_{-}$TEA

3: $\left[\mathrm{Zr}_{12}\left(\mu_{3}-\mathrm{O}\right)_{4}\left(\mu_{2}-\mathrm{OH}\right)_{12}(\mathrm{Cp})_{12}(\overline{\mathrm{bdc}})_{6}\right] \mathrm{Cl}_{4} / \mathrm{Zrbdc}_{-} \mathrm{Cl}$

4: $\left[\mathrm{Zr}_{12}\left(\mu_{3}-\mathrm{O}\right)_{4}\left(\mu_{2}-\mathrm{OH}\right)_{12}(\mathrm{Cp})_{12}(\mathrm{bdc})_{6}\right] \mathrm{OTf}_{4} / \mathrm{Zrbdc}_{-} \mathrm{OTf}$

5: $\left[\mathrm{Zr}_{12}\left(\mu_{3}-\mathrm{O}\right)_{4}\left(\mu_{2}-\mathrm{OH}\right)_{12}(\mathrm{Cp})_{12}\left(\mathrm{Me}_{2}-\mathrm{bdc}\right)_{6}\right] \mathrm{Cl}_{4} / \mathrm{Zr}_{-} \mathrm{Cl}$

6: $\left[\mathrm{Zr}_{12}\left(\mu_{3}-\mathrm{O}\right)_{4}\left(\mu_{2}-\mathrm{OH}\right)_{12}(\mathrm{Cp})_{12}\left(\mathrm{Me}_{2}-\mathrm{bdc}\right)_{6}\right] \mathrm{OTf}_{4} / \mathrm{Zr}_{-} \mathrm{OTf}$

7: $\left[\mathrm{Zr}_{12}\left(\mu_{3}-\mathrm{O}\right)_{4}\left(\mu_{2}-\mathrm{OH}\right)_{12}(\mathrm{Cp})_{12}\left(\mathrm{Me}_{2}-\mathrm{bdc}\right)_{6}\right]_{6}\left[\mathrm{Cu}_{24}\left(\mathrm{SO}_{3}-\mathrm{bdc}\right)_{24}\right] / \mathrm{Zr}-\mathrm{Cu}$

7a: 30 min. addition / $\mathrm{Zr}-\mathrm{Cu}-30$

7b: 150 min. addition / $\mathrm{Zr}-\mathrm{Cu}-150$

7c: 300 min. addition / $\mathrm{Zr}-\mathrm{Cu}-300$

8: $\mathrm{Li}_{16}\left[\mathrm{Zr}_{12}\left(\mu_{3}-\mathrm{O}\right)_{4}\left(\mu_{2}-\mathrm{OH}\right)_{12}(\mathrm{Cp})_{12}\left(\mathrm{Me}_{2}-\mathrm{bdc}\right)_{6}\right]_{2}\left[\mathrm{Cu}_{24}\left(\mathrm{SO}_{3}-\mathrm{bdc}\right)_{24}\right] / \mathrm{Li}_{16} \mathrm{Zr}-\mathrm{Cu}$

9: $\mathrm{TEA}_{16}\left[\mathrm{Zr}_{12}\left(\mu_{3}-\mathrm{O}\right)_{4}\left(\mu_{2}-\mathrm{OH}\right)_{12}(\mathrm{Cp})_{12}\left(\mathrm{Me}_{2}-\mathrm{bdc}\right)_{6}\right]_{2}\left[\mathrm{Cu}_{24}\left(\mathrm{SO}_{3}-\mathrm{bdc}\right)_{24}\right] / \mathrm{TEA}_{16} \mathrm{Zr}-\mathrm{Cu}$

10: $\mathrm{X}_{16}\left[\mathrm{Zr}_{12}\left(\mu_{3}-\mathrm{O}\right)_{4}\left(\mu_{2}-\mathrm{OH}\right)_{12}(\mathrm{Cp})_{12}\left(\mathrm{Me}_{2}-\mathrm{bdc}\right)_{6}\right]_{2}\left[\mathrm{Cu}_{24}\left(\mathrm{SO}_{3}-\mathrm{bdc}\right)_{24}\right] / \mathrm{X}_{16} \mathrm{Zr}-\mathrm{Cu}$ 


\section{Detailed Experimental Procedures}

General Considerations. All reagents were obtained from commercial vendors and used without purification, excluding solvents. N,N-Dimethylformamide (DMF) was obtained from a solvent purification system (SPS) and stored in a brown amber bottle on $4 \AA$ sieves. Thermal stability thermogravimetric analyses (TGA) were carried out with a TA Q5000 SA. Mass Spectrometry Low resolution LCMS experiments were performed using a Waters SQD2 detector (ESI) that was coupled to a Waters Acquity H-Class UPLC. ${ }^{1} \mathrm{H}-\mathrm{NMR}$ spectra were taken on a Bruker $400 \mathrm{MHz}$ spectrometer with a 5-mm Bruker SMART probe and data obtained was manipulated in MestReNova NMR processor software. Low-pressure adsorption measurements were obtained on a Micromeritics Tristar II PLUS at $77 \mathrm{~K}$ or $195 \mathrm{~K}$. Infrared (IR) Spectroscopy measurements were carried out with a Bruker ALPHA II. UV-Vis measurements were carried out with an AvaSpecULS2048CL with a deuterium-halogen light source and a fiber optic reflection probe. PXRD measurements were performed with a Bruker D8 XRD (LynxEye position sensitive detector) operating with a $\mathrm{Cu} \mathrm{K} \alpha 1$ x-ray generator $(\lambda=1.54 \AA)$ with a $40 \mathrm{kV}$ beam voltage and $40 \mathrm{~mA}$ current.

\section{Thermal Stability TGA}

At least $10 \mathrm{mg}$ of sample was loaded onto an aluminum pan. Samples were heated up to $600{ }^{\circ} \mathrm{C}$ at a rate of $2{ }^{\circ} \mathrm{C}$ per minute while exposed to a continuous flow of $\mathrm{N}_{2}$.

\section{Mass Spectrometry}

Generally, $\sim 3 \mathrm{mg}$ of zirconium cage was massed into a $4 \mathrm{~mL}$ vial, then methanol $(4 \mathrm{~mL})$ was added to the vial. Cage solution $(1 \mathrm{~mL})$ was then transferred into a PTFE mass spectrometry vial.

\section{${ }^{\mathbf{1}} \mathrm{H}$ NMR Digestion measurements}

Generally, $\sim 10 \mathrm{mg}$ of sample and $\sim 5 \mathrm{mg}$ of cesium fluoride were added to a $4 \mathrm{~mL}$ vial. Two drops of deuterium chloride solution were added to the sample. The sample was then dissolved in a DMSO: $\mathrm{D}_{2} \mathrm{O}(2: 1)$ mixture. Copper-based cage samples were digested by adding $\sim 10 \mathrm{mg}$ of sample into a $4 \mathrm{~mL}$ vial. Two drops of deuterium chloride solution were added to the sample. DMSO (0.5 $\mathrm{mL}$ ) was then added to the vial. Zirconium-based cage was digested by adding $\sim 10 \mathrm{mg}$ of sample and $\sim 5 \mathrm{mg}$ of cesium fluoride into a $4 \mathrm{~mL}$ vial. $\mathrm{D}_{2} \mathrm{O}(0.5 \mathrm{~mL})$ was then added to the vial.

\section{Gas Adsorption measurements}

Low-pressure adsorption measurements were obtained on a Micromeritics Tristar II PLUS at 77 $\mathrm{K}$ and $195 \mathrm{~K}$ for $\mathrm{N}_{2}$ and $\mathrm{CO}_{2}$, respectively. Generally, benzene washed material $(\sim 100 \mathrm{mg})$ was pipetted into a glass gas adsorption tube, frozen in liquid nitrogen and dried via sublimation of the benzene at $0{ }^{\circ} \mathrm{C}$ under flowing nitrogen until a free-flowing powder was obtained. The dried powder was then put under dynamic vacuum at $75^{\circ} \mathrm{C}$ for 24 hours. Washed copper-based cage samples $(\sim 100 \mathrm{mg})$ were dried under dynamic vacuum at room temperature until a free-flowing powder was obtained. The dried powder was then transferred into a glass gas adsorption tube and dried on a Micromeritics 3-Flex degas station at room temperature. Chloroform washed zirconium cage samples $(\sim 100 \mathrm{mg})$ were dried under dynamic vacuum at room temperature until a freeflowing powder was obtained. The dried powder was then transferred into a glass gas adsorption tube and dried on a Micromeritics 3-Flex degas station at room temperature. Cage sample was finally activated while heating under dynamic vacuum. 


\section{X-ray Photoelectron Spectroscopy (XPS) Analyses}

$\mathrm{X}$-ray photoelectron spectroscopy was conducted using a Fisher K-alpha spectrometer equipped with monochromatic $\mathrm{Al} \mathrm{K} \alpha \mathrm{X}$-rays $(1486.7 \mathrm{eV})$. The operating pressure in the main chamber was less than $1 \times 10-8$ torr. The X-ray spot size on the K-alpha was elliptical in shape with a semimajor axis of roughly $400 \mu \mathrm{m}$. Atomic percentages $\left(X_{\mathrm{i}}\right)$ may be calculated from the high-resolution spectra and were determined using the equation:

$$
X_{\mathrm{i}}=\left(\mathrm{A}_{\mathrm{i}} / \mathrm{S}_{\mathrm{i}}\right) / \sum_{\mathrm{i}} \mathrm{A}_{\mathrm{i}} / \mathrm{S}_{\mathrm{i}}
$$

where $A_{i}$ is the area calculated with a Shirley-type baseline, and $S_{i}$ is the relative sensitivity factor. Atomic percentages do not include hydrogen in XPS. High-resolution XPS spectra were collected at a pass energy of $20 \mathrm{eV}$ using a step size of $0.1 \mathrm{eV}$. For cases in which charging was problematic, compensation was accomplished by engaging a low energy electron/ion flood source in the main analysis chamber of the instruments. Additionally, all binding energies were referenced to the adventitious $\mathrm{C} 1 \mathrm{~s}$ component at $285.0 \mathrm{eV}$.

\section{Scanning Electron Microscopy (SEM)}

Samples were prepared for imaging with scanning electron microscopy by solvent evaporation followed by gold/palladium sputter coating. The samples were then imaged using the Auriga 60 CrossBeam scanning electron microscope at the University of Delaware's Keck Center of Advanced Microscopy and Microanalysis. All samples were imaged using secondary electron emission imaging.

\section{Detailed Synthetic Procedures}

\section{Synthesis of 2,5-Dimethyl-H2bdc}

The following synthesis has been modified from a previously published paper. ${ }^{1}$ In a $\mathrm{N}_{2}$ glovebox, magnesium metal $(0.9 \mathrm{~g}, 37 \mathrm{mmol})$ and anhydrous THF $(50 \mathrm{~mL})$ were measured into a $500 \mathrm{~mL}$ schlenk flask. The schlenk flask was removed from the box and put under flowing $\mathrm{N}_{2}$. 1,4Dibromo-2,5-dimethylbenzene $(2 \mathrm{~g}, 7.6 \mathrm{mmol})$ was then added to the schlenk flask. The mixture was heated to $60^{\circ} \mathrm{C}$ while stirring. Once at temperature, iodine $(0.045 \mathrm{~g}, 0.18 \mathrm{mmol})$ was added to the reaction. The reaction mixture was then allowed to stir at $60^{\circ} \mathrm{C}$ overnight. The reaction was then cooled to room temperature before being placed into a reagent alcohol/dry ice bath. The reaction was allowed to cool for 15 minutes before adding excess dry ice into the schlenk flask. The reaction was then left overnight to slowly warm to room temp. Once warm, $\sim 2 \mathrm{M} \mathrm{HCl}$ solution $(60 \mathrm{~mL})$ was added slowly into the schlenk flask whereupon the reaction bubbled violently. Once the reaction stopped bubbling, $\mathrm{DI} \mathrm{H}_{2} \mathrm{O}(150 \mathrm{~mL})$ was added into the schlenk flask to precipitate desired product. Solid was then collected via vacuum filtration. This procedure was completed multiple times with a typical yield of $0.8 \mathrm{~g}(54 \%) .{ }^{1} \mathrm{H}$ NMR $\left(400 \mathrm{MHz}, 25{ }^{\circ} \mathrm{C}, \mathrm{DMSO}\right) 7.68$, (s, $2 \mathrm{H}), 2.48(\mathrm{~d}, 6 \mathrm{H})$. 


\section{Synthesis of $\left[\mathrm{Zr}_{12}\left(\mu_{3}-\mathrm{O}\right)_{4}\left(\mu_{2}-\mathrm{OH}\right)_{12}(\mathrm{Cp})_{12}\left(\mathrm{Me}_{2}-\mathrm{bdc}\right)_{6}\right] \mathrm{Cl}_{4} / \mathrm{Zr}_{-} \mathrm{Cl}$}

In a $20 \mathrm{~mL}$ vial, zirconocene dichloride $(175 \mathrm{mg}, 0.6 \mathrm{mmol})$ and 2,5-dimethylbenzene-1,4dicarboxylic acid $(96.6 \mathrm{mg}, 0.5 \mathrm{mmol})$ were dissolved in DMF $(10 \mathrm{~mL})$. The stock solution was combined with DI water $(500 \mu \mathrm{L})$ and was heated at $65{ }^{\circ} \mathrm{C}$ for 8 hours. Phase-pure cubic crystals/white crystalline solid was collected via scraping the as synthesized material from the side of the vial. The slurry was then centrifuged and the mother liquor decanted off. Activated material was prepared by washing as synthesized cage in fresh DMF three times, with solvent replaced every 24 hours. The DMF solvated material was then exchanged three times with chloroform, with fresh solvent added every 24 hours. Chloroform solvated material was then activated under dynamic vacuum at $85{ }^{\circ} \mathrm{C}$. This procedure was completed multiple times with a typical yield of $0.1 \mathrm{~g}(59 \%$ based on zirconium).

\section{Synthesis of $\left[\mathrm{Zr}_{12}\left(\mu_{3}-\mathrm{O}\right)_{4}\left(\mu_{2}-\mathrm{OH}\right)_{12}\left(\mathrm{Cp}_{12}\left(\mathrm{Me}_{2}-\mathrm{bdc}\right)_{6}\right] \mathrm{OTf}_{4} / \mathrm{Zr}_{-} \mathrm{OTf}\right.$}

$\left[\mathrm{Zr}_{12}\left(\mu_{3}-\mathrm{O}\right)_{4}\left(\mu_{2}-\mathrm{OH}\right)_{12}(\mathrm{Cp})_{12}\left(\mathrm{Me}_{2}-\mathrm{bdc}\right)_{6}\right] \mathrm{Cl}_{4} \cdot 16 \mathrm{DMF} \quad(200 \mathrm{mg}, 0.0436 \mathrm{mmol})$ and silver trifluoromethanesulfonate $(43.4 \mathrm{mg}, 0.169 \mathrm{mmol})$ were combined in a tinfoil wrapped $20 \mathrm{~mL}$ scintillation vial. Methanol $(10 \mathrm{~mL})$ was added to the vial. The resulting mixture was stirred in darkness at room temperature for 3 days. The resulting slurry was then centrifuged, and the mother liquor removed via pipet. The methanol was then removed under reduced pressure resulting in offwhite cage product. Activated material was prepared by washing as synthesized cage in fresh DMF three times, with solvent replaced every 24 hours. The DMF solvated material was then exchanged three times with chloroform, with fresh solvent added every 24 hours. Chloroform solvated material was then activated under dynamic vacuum at $100{ }^{\circ} \mathrm{C}$. Single-crystal quality material was obtained by dissolving the white powder in methanol and recrystallizing via diffusion with ethyl acetate. ${ }^{1} \mathrm{H}$ NMR $\left(400 \mathrm{MHz}, 25{ }^{\circ} \mathrm{C}\right.$, Methanol- $\left.d_{4}\right) 7.77(\mathrm{~s}, 12 \mathrm{H}), 6.63(\mathrm{~s}, 60 \mathrm{H}), 2.65(\mathrm{~s}, 36 \mathrm{H})$, residual DMF peaks at 7.98, 2.99 and 2.86. This procedure was completed multiple times with a typical yield of $0.155 \mathrm{~g}\left(77.5 \%\right.$ based on $\left.\mathrm{Zr} \_\mathrm{Cl}\right)$.

\section{Synthesis of $\mathrm{Li}_{24}\left[\mathrm{Cu}_{24}\left(\mathrm{SO}_{3}-\text {-bdc }\right)_{24}\right] / \mathrm{Cu}_{-} \mathrm{Li}$}

Copper acetate monohydrate $(200 \mathrm{mg}, 1 \mathrm{mmol})$ and 5-sulfoisophthalic acid monolithium salt (252 $\mathrm{mg}, 1 \mathrm{mmol}$ ) were added into a $65 \mathrm{~mL}$ steel drum with two $1 \mathrm{~cm}$ diameter steel ball bearings. The resulting mixture was milled for 90 minutes. The resulting blue powder was then dissolved in formamide $(4 \mathrm{~mL})$ and transferred into a $20 \mathrm{~mL}$ scintillation vial. Ethyl acetate $(16 \mathrm{~mL})$ was added to the vial. The vial was shaken and then placed at a 45-degree angle and allowed to sit at room temperature for 12 hours. A dark blue viscous gel formed at the bottom of the vial. The mother liquor was removed from the vial via pipet and then tetrahydrofuran $(18 \mathrm{~mL})$ was added to the vial resulting in a blue powder. Solvent was replaced two times with fresh THF $(20 \mathrm{~mL})$, with solvent replaced every 24 hours. Dry powder was obtained by removing the THF via pipet and allowing the sample to dry under flowing nitrogen at room temperature. This procedure was completed multiple times with a typical yield of $0.2 \mathrm{~g}$ (64 \% based on copper). Material was recrystallized via diffusion by dissolving sample in formamide and using acetone as the anti-solvent. ${ }^{1} \mathrm{H}$ NMR (400 MHz, $\left.25^{\circ} \mathrm{C}, \mathrm{DMSO}\right) 8.34$ (t, 24H), 8.28 (t, 48H). 


\section{Synthesis of TEA ${ }_{24}\left[\mathrm{Cu}_{24}\left(\mathrm{SO}_{3}-\mathrm{bdc}\right)_{24}\right] / \mathrm{Cu}$ TEA}

$\mathrm{Li}_{24}\left[\mathrm{Cu}_{24}\left(\mathrm{SO}_{3} \text {-bdc }\right)_{24}\right] \cdot 55$ Formamide $(133 \mathrm{mg}, 0.013 \mathrm{mmol})$ was dissolved in methanol $(10 \mathrm{~mL})$. Dowex 50WX8 hydrogen form 100-200 mesh beads $(10 \mathrm{~mL})$ were put into a $100 \mathrm{~mL}$ VWR jar. Tetraethylammonium hydroxide solution $\left(1 \mathrm{M}\right.$ in $\left.\mathrm{H}_{2} \mathrm{O}\right)(34 \mathrm{~mL})$ was added to the VWR jar. The mixture was stirred for 24 hours at room temperature. The salt metathesized beads (TEA form beads) were pipetted into a $20 \mathrm{~mL}$ scintillation vial and washed with fresh methanol $(10 \mathrm{~mL})$ three times. TEA form beads $(3 \mathrm{~mL})(5.1 \mathrm{~mol}$ equivalents) were pipetted into a $5 \mathrm{~mL}$ BD syringe with a minimum amount of Kimtech wipe in the bottom of the syringe. A $20 \mathrm{~mL}$ BD syringe was then placed inside the top of the $5 \mathrm{~mL}$ syringe. The $\mathrm{Li}_{24}\left[\mathrm{Cu}_{24}\left(\mathrm{SO}_{3}-\mathrm{bdc}\right)_{24}\right] \cdot 55$ Formamide solution was then added to the $20 \mathrm{~mL}$ syringe and allowed to drop through the column of TEA form beads, collected in a $20 \mathrm{~mL}$ scintillation vial. Once through, fresh methanol $(10 \mathrm{~mL})$ was added to the 20 $\mathrm{mL} \mathrm{BD}$ syringe and allowed to wash the column for residual $\mathrm{Cu}_{24}\left(\mathrm{SO}_{3}-\mathrm{BDC}\right)_{24} \mathrm{TEA}_{24}$ cage. The resulting dark blue methanol solution was dried under reduced pressure resulting in a light blue cage powder. This procedure was completed multiple times with a typical yield of $0.1 \mathrm{~g}$ (75\% based on $\mathrm{Cu}$ _Li). The cage was recrystallized via a diffusion by dissolving sample in formamide and using ethyl acetate as the anti-solvent. ${ }^{1} \mathrm{H}$ NMR $\left(400 \mathrm{MHz}, 25^{\circ} \mathrm{C}, \mathrm{DMSO}\right) 8.36(\mathrm{t}, 24 \mathrm{H}), 8.28$ $(\mathrm{t}, 48 \mathrm{H}), 3.16(\mathrm{q}, 206 \mathrm{H}), 1.12(\mathrm{t}, 314 \mathrm{H})$.

\section{Synthesis of $\mathrm{TEA}_{16}\left[\mathrm{Zr}_{12}\left(\mu_{3}-\mathrm{O}\right)_{4}\left(\mu_{2}-\mathrm{OH}\right)_{12}(\mathrm{Cp})_{12}\left(\mathrm{Me}_{2}-\mathrm{bdc}\right)_{6}\right]_{2}\left[\mathrm{Cu}_{24}\left(\mathrm{SO}_{3}-\mathrm{bdc}\right)_{24}\right]$ Single Crystals}

$\mathrm{TEA}_{24}\left[\mathrm{Cu}_{24}\left(\mathrm{SO}_{3} \text {-bdc }\right)_{24}\right] \cdot 48$ Formamide $(84 \mathrm{mg}, 0.006 \mathrm{mmol})$ was measured into a $20 \mathrm{~mL}$ scintillation vial and dissolved in methanol $(20 \mathrm{~mL})$. $\left[\mathrm{Zr}_{12}\left(\mu_{3}-\mathrm{O}\right)_{4}\left(\mu_{2}-\mathrm{OH}\right)_{12}(\mathrm{Cp})_{12}\left(\mathrm{Me}_{2}-\right.\right.$ bdc) ${ }_{6} \mathrm{OTf}_{4} \cdot 16 \mathrm{DMF}(169 \mathrm{mg}, 0.038 \mathrm{mmol})$ was measured into a $20 \mathrm{~mL}$ scintillation vial and dissolved in DMF $(20 \mathrm{~mL})$. The zirconium solution $(1 \mathrm{~mL})$ was pipetted into the bottom of an NMR tube. Methanol: DMF (1:1) $(0.5 \mathrm{~mL})$ was slowly layered on top of the zirconium cage solution. The copper cage $(1 \mathrm{~mL})$ was then slowly pipetted into the NMR tube. The NMR tube was then capped and left to sit at room temperature. Single crystals were seen growing after two weeks, with single-crystal quality crystals harvested after three months.

\section{General Synthesis of Porous Salt Zr-Cu-Time Dependent Samples}

$\mathrm{Li}_{24}\left[\mathrm{Cu}_{24}\left(\mathrm{SO}_{3} \text {-bdc }\right)_{24}\right] \cdot 55$ Formamide $(65 \mathrm{mg}, 0.006 \mathrm{mmol})$ was measured into a $20 \mathrm{~mL}$ scintillation vial and dissolved in methanol $(20 \mathrm{~mL})$. $\left[\mathrm{Zr}_{12}\left(\mu_{3}-\mathrm{O}\right)_{4}\left(\mu_{2}-\mathrm{OH}\right)_{12}(\mathrm{Cp})_{12}\left(\mathrm{Me}_{2}-\right.\right.$ bdc) ${ }_{6} \mathrm{OTf}_{4} \cdot 16 \mathrm{DMF}(169 \mathrm{mg}, 0.038 \mathrm{mmol})$ was measured into a $20 \mathrm{~mL}$ scintillation vial and dissolved in methanol $(20 \mathrm{~mL})$. Solutions were transferred into $20 \mathrm{~mL}$ BD syringes then attached to deflected point septum penetration needles $(20 \mathrm{~g} \times 8$ "). The syringes were placed into Fisherbrand single syringe pumps with the ends of the penetration needles placed through a 24/40 septum. Fresh methanol $(10 \mathrm{~mL})$ was placed into a $100 \mathrm{~mL}$ round bottom flask, then the septum was placed into the flask. Syringe pump settings were set to the following: volume: $20.1 \mathrm{~mL}$ and rate: $\mathrm{t}=30 \mathrm{~min} .: 40.2 \mathrm{~mL} /$ hour, $\mathrm{t}=150 \mathrm{~min} .: 8.04 \mathrm{~mL} /$ hour, and $\mathrm{t}=300 \mathrm{~min} .: 4.02 \mathrm{~mL} /$ hour. The two solutions were added together at room temperature and stirred for 1 hour following full addition at $200 \mathrm{rpm}$. The resulting slurry was centrifuged down with the mother liquor then removed via pipet. The resulting blue powder was washed with fresh methanol $(20 \mathrm{~mL})$. Solvent exchange was then completed by washing the blue powder with benzene three times, with solvent 
replaced every 24 hours. Activated material was obtained by pipetting benzene solvated material into the bottom if a glass gas adsorption tube and subliming the benzene via flowing nitrogen at 0 ${ }^{\circ} \mathrm{C}$. Finally, the dry blue powder was dried at $75{ }^{\circ} \mathrm{C}$ under flowing nitrogen. This procedure was completed multiple times with a typical yield of $0.15 \mathrm{~g}(84 \%$ based on expected de-solvated yield for an ideal product: $0.178 \mathrm{~g}) .{ }^{1} \mathrm{H}$ NMR $\left(400 \mathrm{MHz}, 25^{\circ} \mathrm{C}\right.$, DMSO) 10.70, 10.58 (s, s, 72H), 9.81 $(\mathrm{d}, 73 \mathrm{H}), 4.59(\mathrm{~s}, 229 \mathrm{H})$.

\section{Synthesis of $\left[\mathrm{Zr}_{12}\left(\mu_{3}-\mathrm{O}\right)_{4}\left(\mu_{2}-\mathrm{OH}\right)_{12}(\mathrm{Cp})_{12}\left(\mathrm{Me}_{2}-\mathrm{bdc}\right)_{6}\right]_{6}\left[\mathrm{Cu}_{24}\left(\mathrm{SO}_{3}-\mathrm{bdc}\right)_{24}\right]$ 2:1 Charge Ratio} $\mathrm{Li}_{24}\left[\mathrm{Cu}_{24}\left(\mathrm{SO}_{3} \text {-bdc }\right)_{24}\right] \cdot 55$ Formamide $(130 \mathrm{mg}, 0.012 \mathrm{mmol})$ was measured into a $20 \mathrm{~mL}$ scintillation vial and dissolved in methanol $(20 \mathrm{~mL})$. $\left[\mathrm{Zr}_{12}\left(\mu_{3}-\mathrm{O}\right)_{4}\left(\mu_{2}-\mathrm{OH}\right)_{12}(\mathrm{Cp})_{12}\left(\mathrm{Me}_{2}-\right.\right.$ bdc)6] $\mathrm{OTf}_{4} \cdot 16 \mathrm{DMF}(169 \mathrm{mg}, 0.038 \mathrm{mmol})$ was measured into a $20 \mathrm{~mL}$ scintillation vial and dissolved in methanol $(20 \mathrm{~mL})$. Solutions were transferred into $20 \mathrm{~mL}$ BD syringes then attached to deflected point septum penetration needles $(20 \mathrm{~g} \times 8$ "). The syringes were placed into Fisherbrand single syringe pumps with the ends of the penetration needles placed through a 24/40 septum. Fresh methanol $(10 \mathrm{~mL})$ was placed into a $100 \mathrm{~mL}$ round bottom flask, then the septum was placed into the flask. Syringe pump settings were set to the following: volume: $20.1 \mathrm{~mL}$ and rate: $40.2 \mathrm{~mL} /$ hour. The two solutions were added together at room temperature and stirred for 1 hour following full addition at $200 \mathrm{rpm}$. The resulting slurry was centrifuged down with the mother liquor then removed via pipet. The resulting blue powder was washed with fresh methanol (20 $\mathrm{mL}$ ). Solvent exchange was then completed by washing the blue powder with benzene three times, with solvent replaced every 24 hours. Activated material was obtained by pipetting benzene solvated material into the bottom if a glass gas adsorption tube and subliming the benzene via flowing nitrogen at $0{ }^{\circ} \mathrm{C}$. Finally, the dry blue powder was dried at $75^{\circ} \mathrm{C}$ under flowing nitrogen. ${ }^{1} \mathrm{H}$ NMR (400 MHz, $\left.25^{\circ} \mathrm{C}, \mathrm{DMSO}\right) 10.68,10.58$ (s, s, 72H), 9.79 (d, 22H), 4.57 (s, 75H).

\section{Synthesis of $\left[\mathrm{Zr}_{12}\left(\mu_{3}-\mathrm{O}\right)_{4}\left(\mu_{2}-\mathrm{OH}\right)_{12}(\mathrm{Cp})_{12}\left(\mathrm{Me}_{2}-\mathrm{bdc}\right)_{6}\right]_{6}\left[\mathrm{Cu}_{24}\left(\mathrm{SO}_{3}-\mathrm{bdc}\right)_{24}\right]$ 1:2 Charge Ratio}

$\mathrm{Li}_{24}\left[\mathrm{Cu}_{24}\left(\mathrm{SO}_{3} \text {-bdc }\right)_{24}\right] \cdot 55$ Formamide $(65 \mathrm{mg}, 0.006 \mathrm{mmol})$ was measured into a $20 \mathrm{~mL}$ scintillation vial and dissolved in methanol $(20 \mathrm{~mL})$. $\left[\mathrm{Zr}_{12}\left(\mu_{3}-\mathrm{O}\right)_{4}\left(\mu_{2}-\mathrm{OH}\right)_{12}(\mathrm{Cp})_{12}\left(\mathrm{Me}_{2}-\right.\right.$ bdc $\left.)_{6}\right]_{\mathrm{OTf}_{4}} \cdot 16 \mathrm{DMF}(338 \mathrm{mg}, 0.076 \mathrm{mmol})$ was measured into a $20 \mathrm{~mL}$ scintillation vial and dissolved in methanol $(20 \mathrm{~mL})$. Solutions were transferred into $20 \mathrm{~mL}$ BD syringes then attached to deflected point septum penetration needles ( $\left.20 \mathrm{~g} \times 8^{\prime \prime}\right)$. The syringes were placed into Fisherbrand single syringe pumps with the ends of the penetration needles placed through a 24/40 septum. Fresh methanol $(10 \mathrm{~mL})$ was placed into a $100 \mathrm{~mL}$ round bottom flask, then the septum was placed into the flask. Syringe pump settings were set to the following: volume: $20.1 \mathrm{~mL}$ and rate: $40.2 \mathrm{~mL} /$ hour. The two solutions were added together at room temperature and stirred for 1 hour following full addition at $200 \mathrm{rpm}$. The resulting slurry was centrifuged down with the mother liquor then removed via pipet. The resulting blue powder was washed with fresh methanol (20 $\mathrm{mL}$ ). Solvent exchange was then completed by washing the blue powder with benzene three times, with solvent replaced every 24 hours. Activated material was obtained by pipetting benzene solvated material into the bottom of a glass gas adsorption tube and subliming the benzene via flowing nitrogen at $0{ }^{\circ} \mathrm{C}$. Finally, the dry blue powder was dried at $75^{\circ} \mathrm{C}$ under flowing nitrogen. ${ }^{1} \mathrm{H}$ NMR (400 MHz, $25^{\circ} \mathrm{C}$, DMSO) 10.69, 10.59 (s, s, 72H), 9.81 (d, 55H), 4.60 (s, 180H). 
Synthesis of TEA $\mathrm{A}_{16}\left[\mathrm{Zr}_{12}\left(\mu_{3}-\mathrm{O}\right)_{4}\left(\mu_{2}-\mathrm{OH}\right)_{12}(\mathrm{Cp})_{12}\left(\mathrm{Me}_{2}-\mathrm{bdc}\right)_{6}\right]_{2}\left[\mathrm{Cu}_{24}\left(\mathrm{SO}_{3}-\mathrm{bdc}\right)_{24}\right] / \mathrm{TEA}_{16} \mathrm{Zr}-\mathrm{Cu}$ $\mathrm{TEA}_{24}\left[\mathrm{Cu}_{24}\left(\mathrm{SO}_{3} \text {-bdc }\right)_{24}\right] \cdot 48$ Formamide $(84 \mathrm{mg}, 0.006 \mathrm{mmol})$ was measured into a $20 \mathrm{~mL}$ scintillation vial and dissolved in methanol $(20 \mathrm{~mL})$. $\quad\left[\mathrm{Zr}_{12}\left(\mu_{3}-\mathrm{O}\right)_{4}\left(\mu_{2}-\mathrm{OH}\right)_{12}(\mathrm{Cp})_{12}\left(\mathrm{Me}_{2}-\right.\right.$ bdc $\left.)_{6}\right] \mathrm{OTf}_{4} \cdot 16 \mathrm{DMF}(169 \mathrm{mg}, 0.038 \mathrm{mmol})$ was measured into a $20 \mathrm{~mL}$ scintillation vial and dissolved in methanol $(20 \mathrm{~mL})$. Solutions were transferred into $20 \mathrm{~mL}$ BD syringes then attached to deflected point septum penetration needles (20g x 8 "). The syringes were placed into Fisherbrand single syringe pumps with the ends of the penetration needles placed through a 24/40 septum. Fresh methanol $(10 \mathrm{~mL})$ was placed into a $100 \mathrm{~mL}$ round bottom flask, then the septum was placed into the flask. Syringe pump settings were set to the following: volume: $20.1 \mathrm{~mL}$ and rate: $40.2 \mathrm{~mL} /$ hour. The two solutions were added together at room temperature and stirred for 18 hours following full addition at $200 \mathrm{rpm}$. The resulting slurry was centrifuged down with the mother liquor then removed via pipet. The resulting blue powder was washed with fresh methanol $(20 \mathrm{~mL})$. Solvent exchange was then completed by washing the blue powder with benzene three times, with solvent replaced every 24 hours. Activated material was obtained by pipetting benzene solvated material into the bottom if a glass gas adsorption tube and subliming the benzene via flowing nitrogen at $0{ }^{\circ} \mathrm{C}$. Finally, the dry blue powder was dried at $50{ }^{\circ} \mathrm{C}$ under flowing nitrogen. 


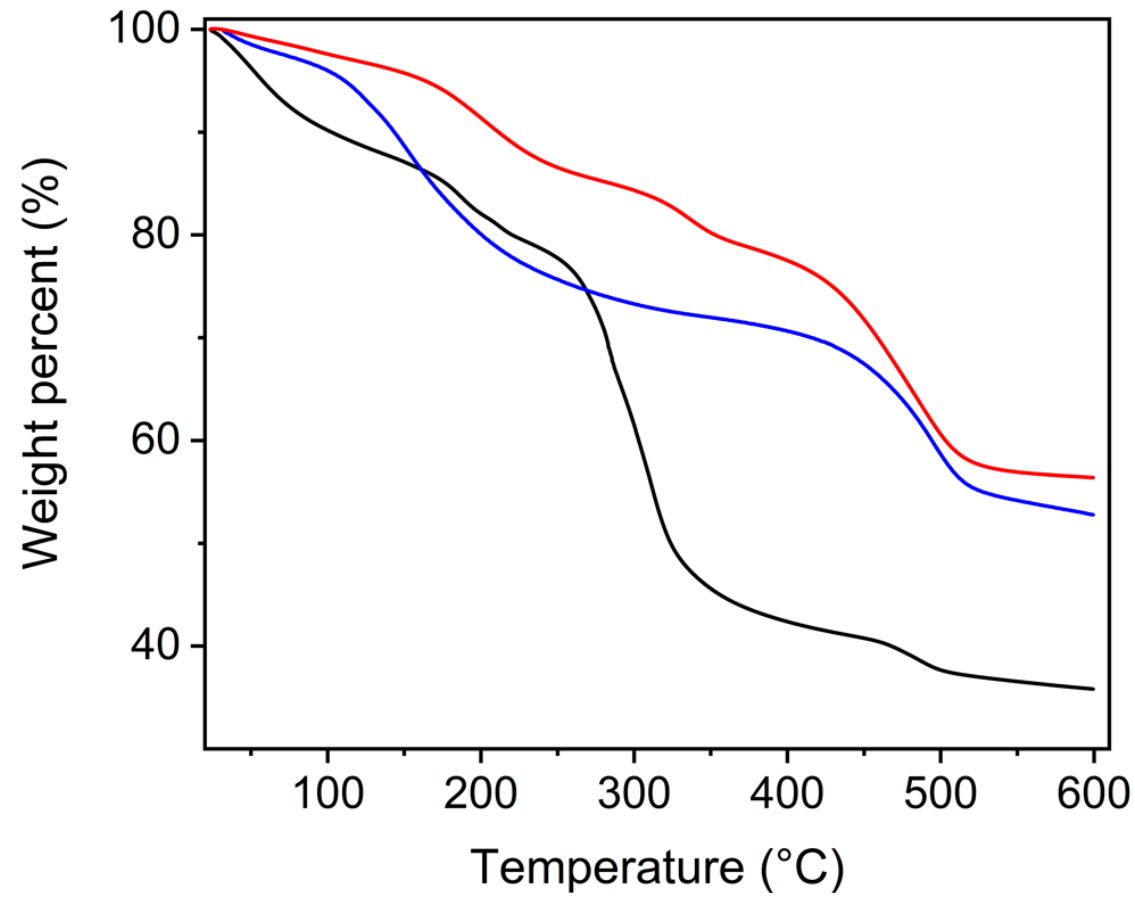

Figure S1 - Thermogravimetric analysis of activated Zr-Cu-30 (red), Zr_OTf(blue), and Cu_Li (black).

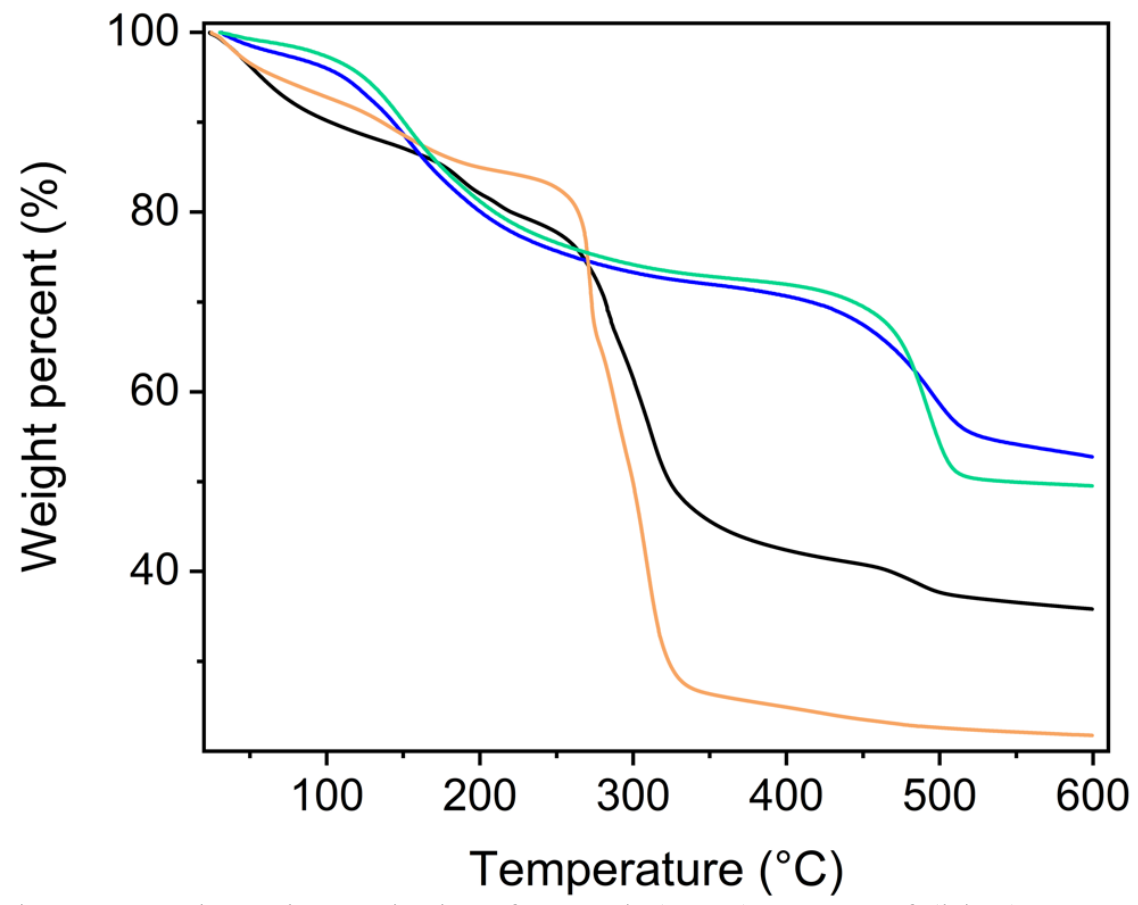

Figure S2 - Thermogravimetric analysis of $\mathrm{Zr} \_\mathrm{Cl}$ (cyan), Zr_OTf (blue), $\mathrm{Cu}$ LLi (black), and $\mathrm{Cu}$ TEA (orange). 

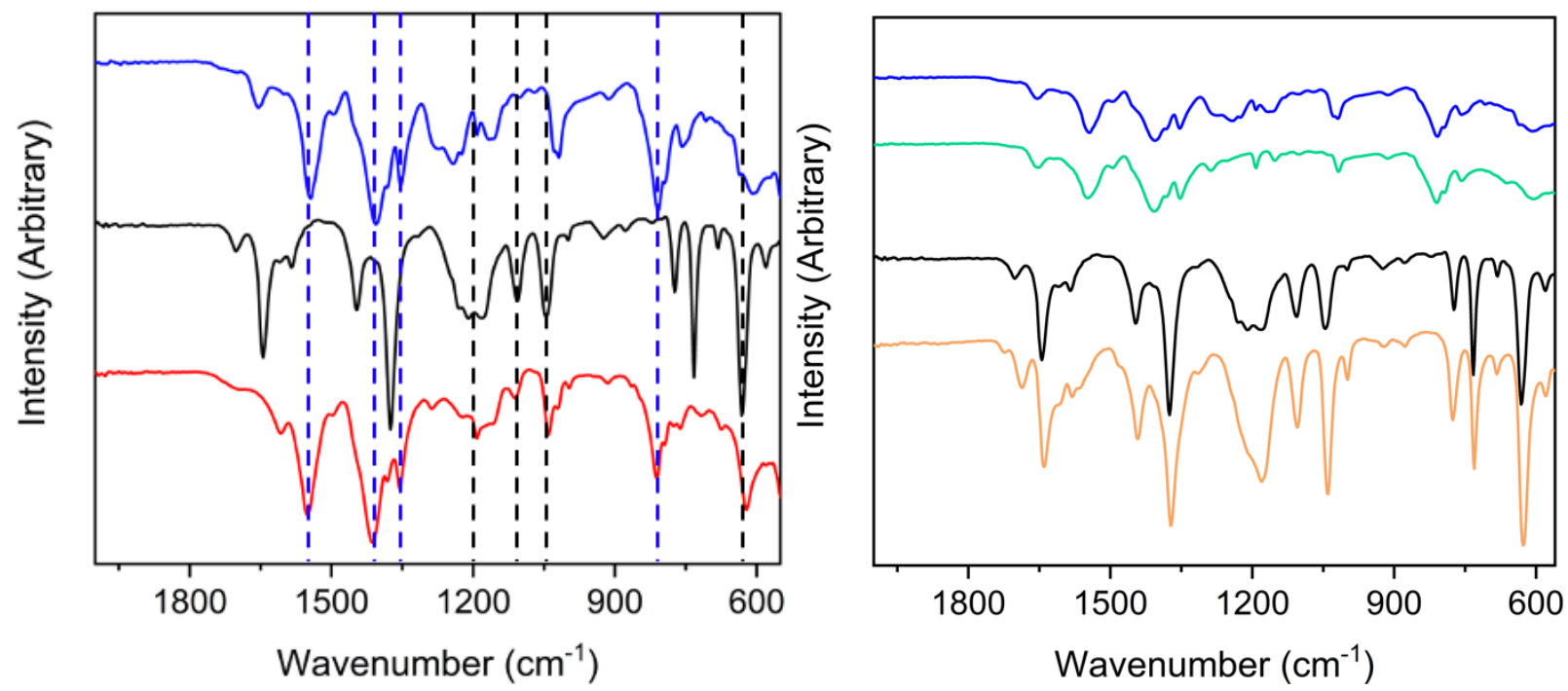

Figure S3 - (Left) Dotted lines show the contribution of select peaks from Zr_OTf (blue) and $\mathrm{Cu} \_\mathrm{Li}$ (black) to $\mathrm{Zr}-\mathrm{Cu}-30$ (red). The strong peak in $\mathrm{Cu} \mathrm{Li}$ (black) at $1650 \mathrm{~cm}^{-1}$ is indictive of $\mathrm{C}=\mathrm{O}$ stretching in formamide, this peak is not present in the Porous Salt $\mathrm{Zr}-\mathrm{Cu}-30$ (red) spectra as this material was synthesized and washed in methanol. (Right) Infrared spectra of Zr_OTf (blue), $\mathrm{Zr} \_\mathrm{Cl}(\mathrm{cyan}), \mathrm{Cu} \mathrm{Li}$ (black), and $\mathrm{Cu} \mathrm{C}_{\text {TEA (orange). }}$

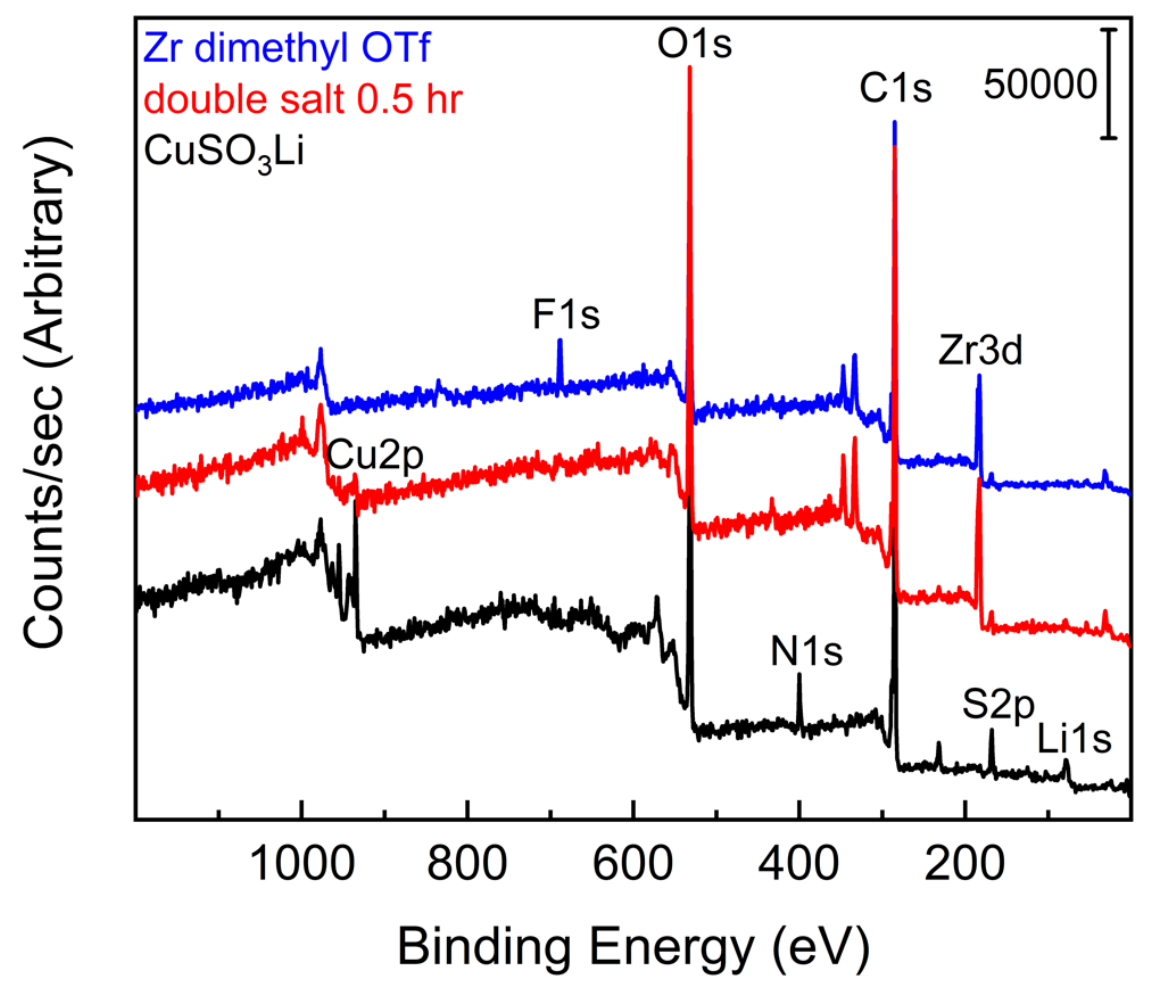

Figure S4 - XPS survey spectra for activated Cu_Li (black), Zr_OTf(blue), and Zr-Cu-30 (red). 

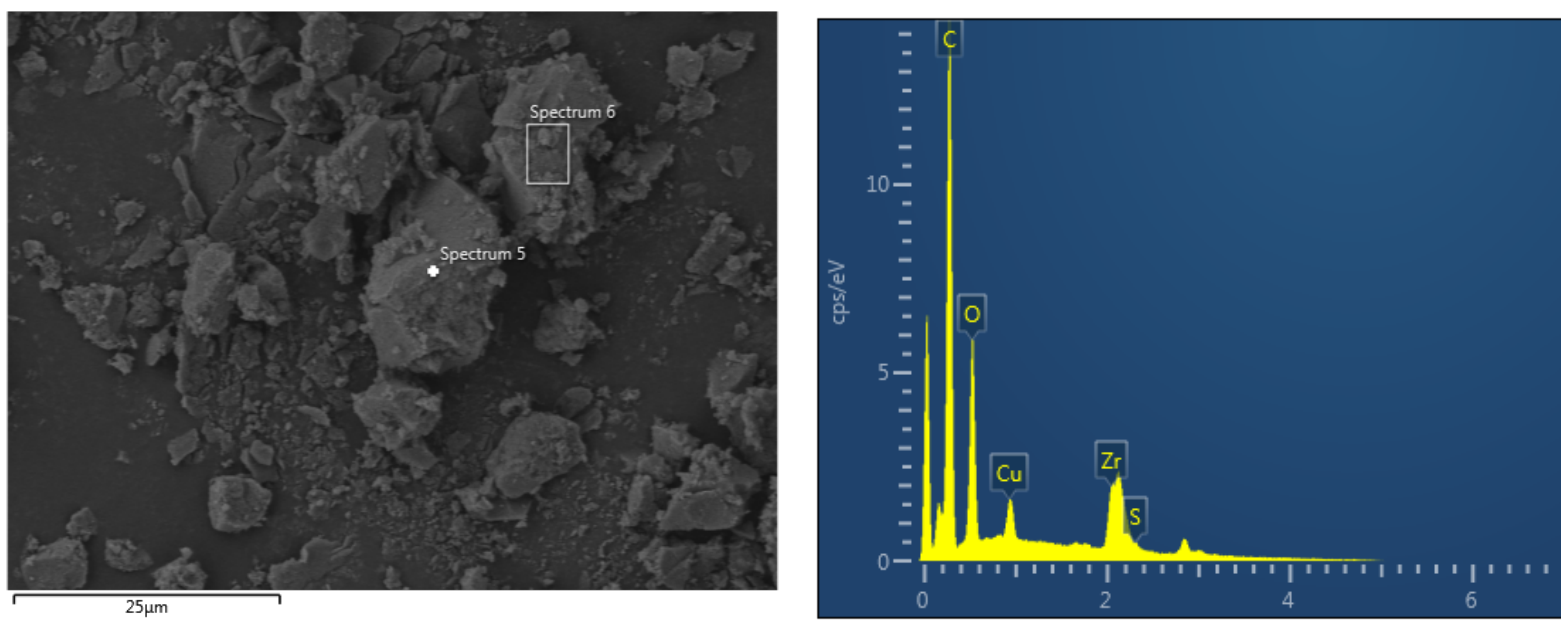

Figure S5 - (Left) Scanning Electron Microscope image of activated Zr-Cu-30. (Right) Energydispersive X-ray spectroscopy spectrum 1 of $\mathrm{Zr}-\mathrm{Cu}-30$. Weight percent of copper found is 5.8 and zirconium is 35.3 , corresponding to $\mathrm{Cu}$ : $\mathrm{Zr}$ cage ratio of 1:6.1.

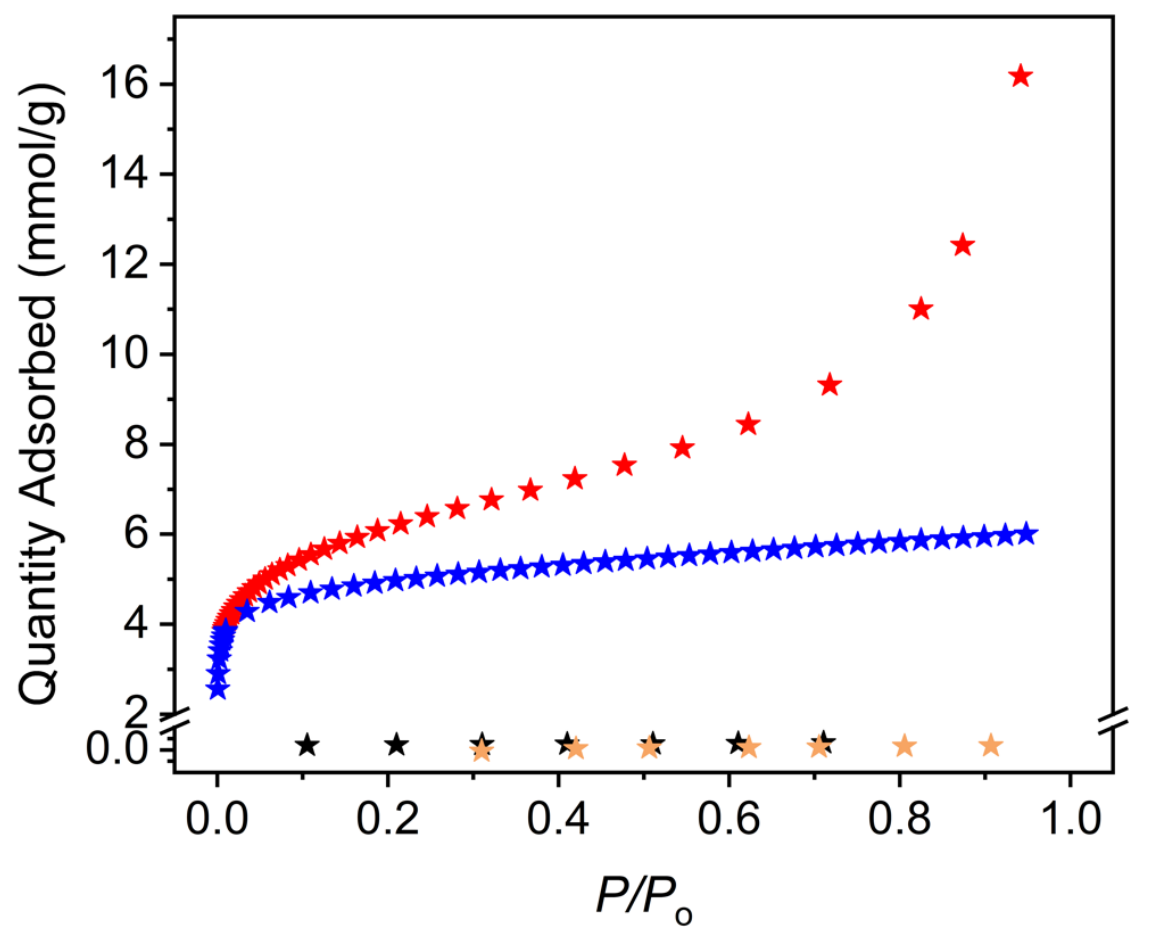

Figure S6 $-\mathrm{N}_{2}$ Adsorption isotherm at $77 \mathrm{~K}$ of $\mathrm{Zr}-\mathrm{Cu}-30$ (red), Zr_OTf (blue), Cu_Li (black), and $\mathrm{Cu}$ TEA (orange). 

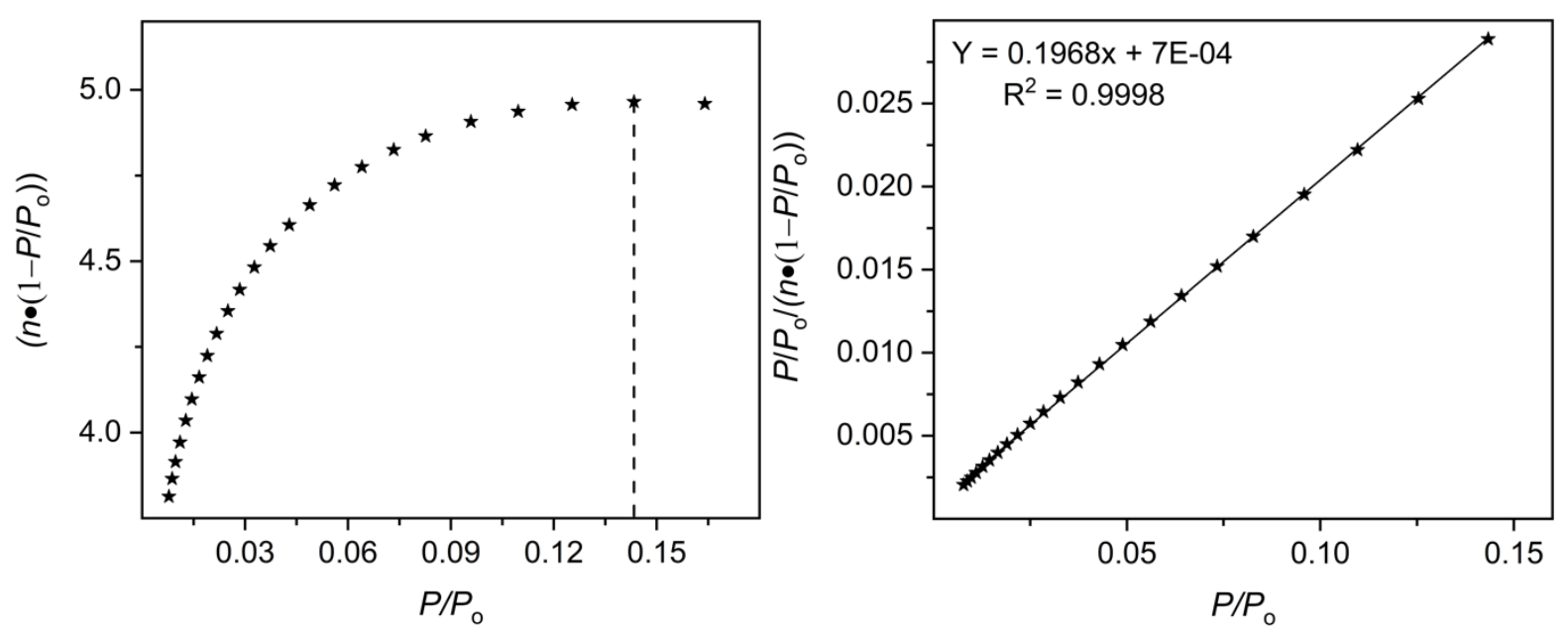

Figure S7 - Plot of $n \bullet\left(1-P / P_{\mathrm{O}}\right)$ vs $P / P_{\mathrm{O}}$ to determine the maximum $P / P_{\mathrm{O}}$ used in the BET linear fit according to the first BET consistency criterion for $\mathrm{N}_{2}$ adsorption at $77 \mathrm{~K}$ of $\mathrm{Zr}-\mathrm{Cu}$. (Right) Plot of $\left(P / P_{\mathrm{O}}\right) /\left(n \bullet\left(1-P / P_{\mathrm{O}}\right)\right)$ vs $P / P_{\mathrm{O}}$ to determine the BET surface area for $\mathrm{N}_{2}$ adsorption at $77 \mathrm{~K}$ of $\mathrm{Zr}-\mathrm{Cu}$. The slope of the best fit lit for $P / P_{\mathrm{O}}<0.143$ is 0.1968 and the $\mathrm{y}$-intercept is 0.0007 , which satisfies the second BET consistency criterion. This results in a surface area of $495.7 \mathrm{~m}^{2} / \mathrm{g}$.
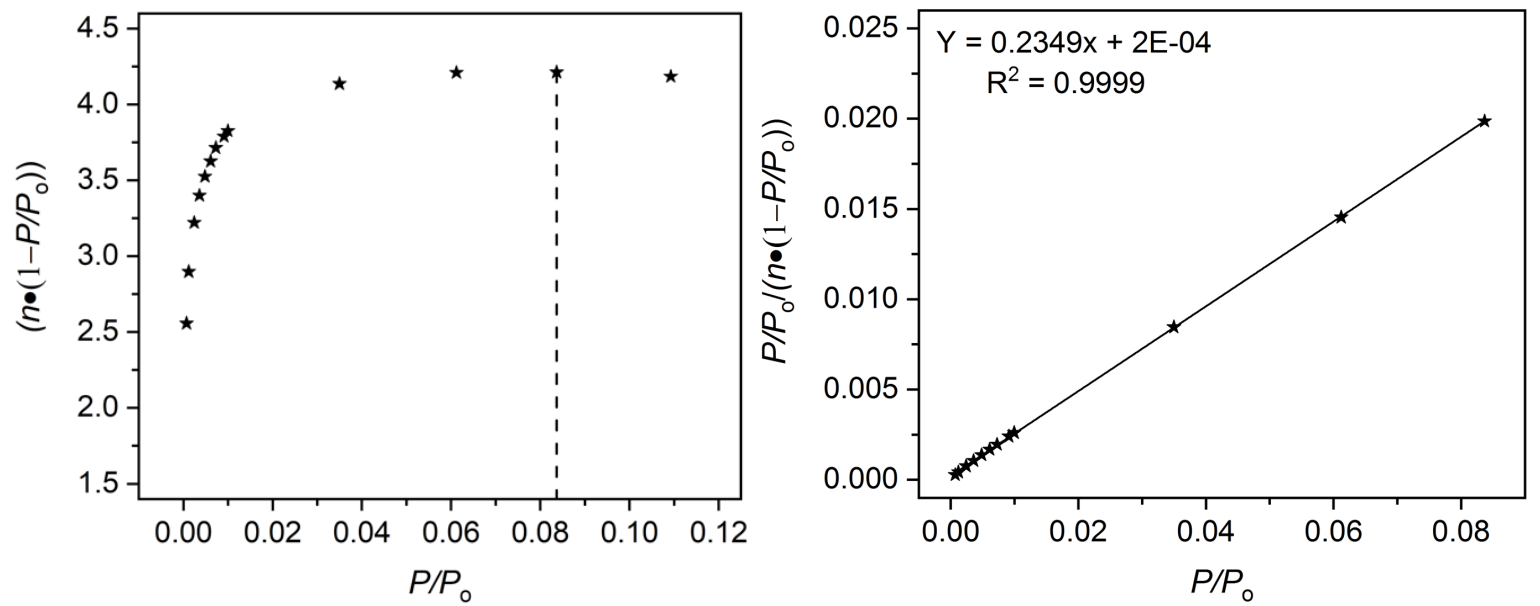

Figure S8 - (Left) Plot of $n \bullet\left(1-P / P_{\mathrm{O}}\right)$ vs $P / P_{\mathrm{O}}$ to determine the maximum $P / P_{\mathrm{O}}$ used in the BET linear fit according to the first BET consistency criterion for $\mathrm{N}_{2}$ adsorption at $77 \mathrm{~K}$ of $\mathrm{Zr}$ OTf. (Right) Plot of $\left(P / P_{\mathrm{O}}\right) /\left(n \bullet\left(1-P / P_{\mathrm{O}}\right)\right)$ vs $P / P_{\mathrm{O}}$ to determine the BET surface area for $\mathrm{N}_{2}$ adsorption at $77 \mathrm{~K}$ of $\mathrm{Zr}$ OOTf. The slope of the best fit lit for $P / P_{\mathrm{O}}<0.084$ is 1.1281 and the $y$-intercept is 0.0016 , which satisfies the second BET consistency criterion. This results in a surface area of 415.5 $\mathrm{m}^{2} / \mathrm{g}$. 
<smiles>O=C(O)c1cc(C(=O)O)cc(S(=O)(=O)[O-])c1</smiles>
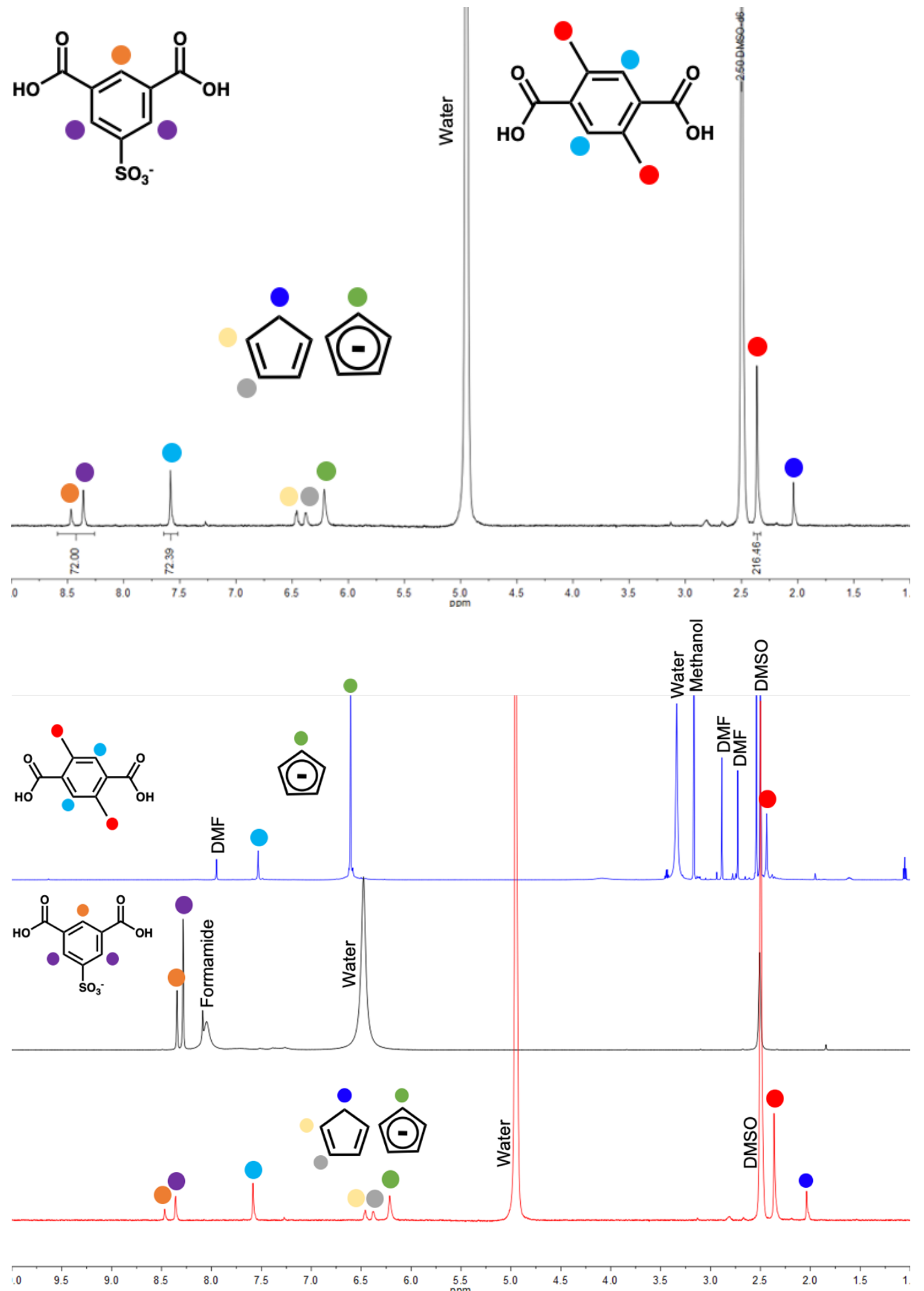

Figure S9 - (Top) ${ }^{1} \mathrm{H}$ NMR analysis of digested Zr-Cu-30 in DMSO. (Bottom) ${ }^{1} \mathrm{H}$ NMR analysis of digested $\mathrm{Zr}-\mathrm{Cu}-30$ in DMSO (red), Zr_OTf cage dissolved in DMSO (blue), and digested Cu_Li cage (black). 


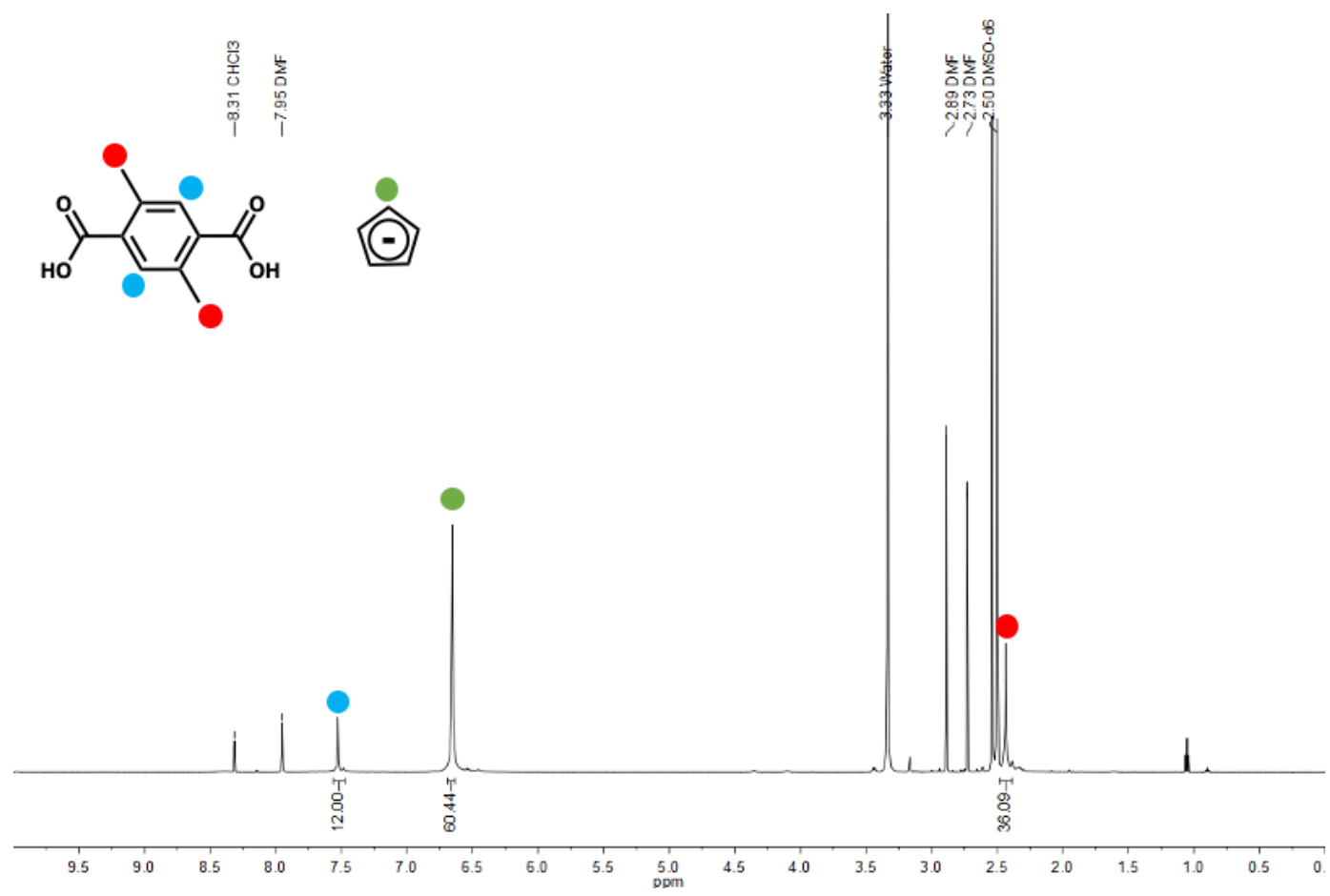

Figure S10 - ${ }^{1} \mathrm{H}$ NMR analysis of $\mathrm{Zr} \_\mathrm{Cl}$ in DMSO.

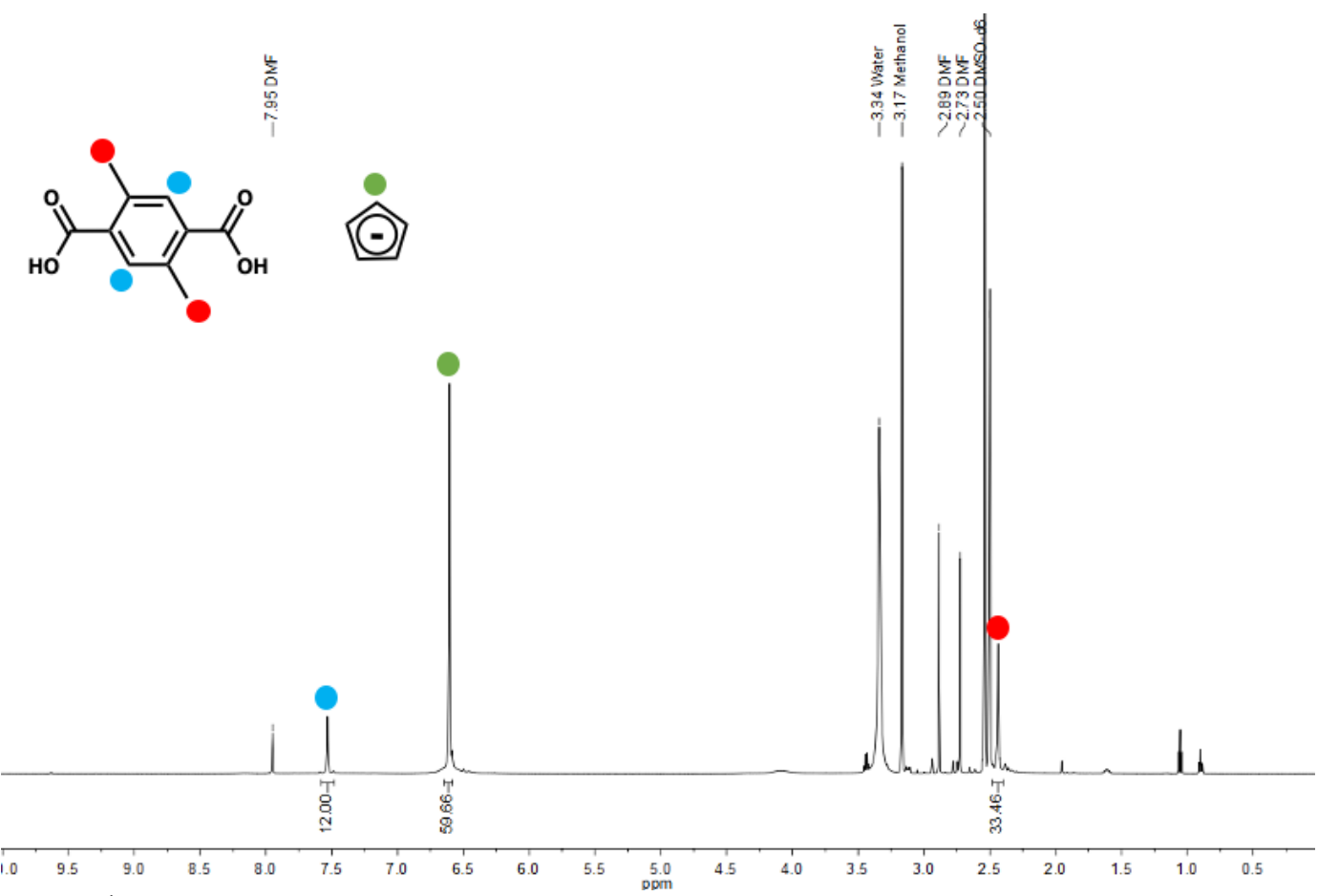

Figure S11 $-{ }^{1} \mathrm{H}$ NMR analysis of Zr_OTf in DMSO. 


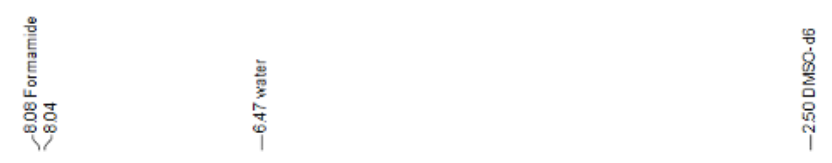<smiles>O=C(O)c1cc([18O])cc(C(=O)O)c1</smiles>

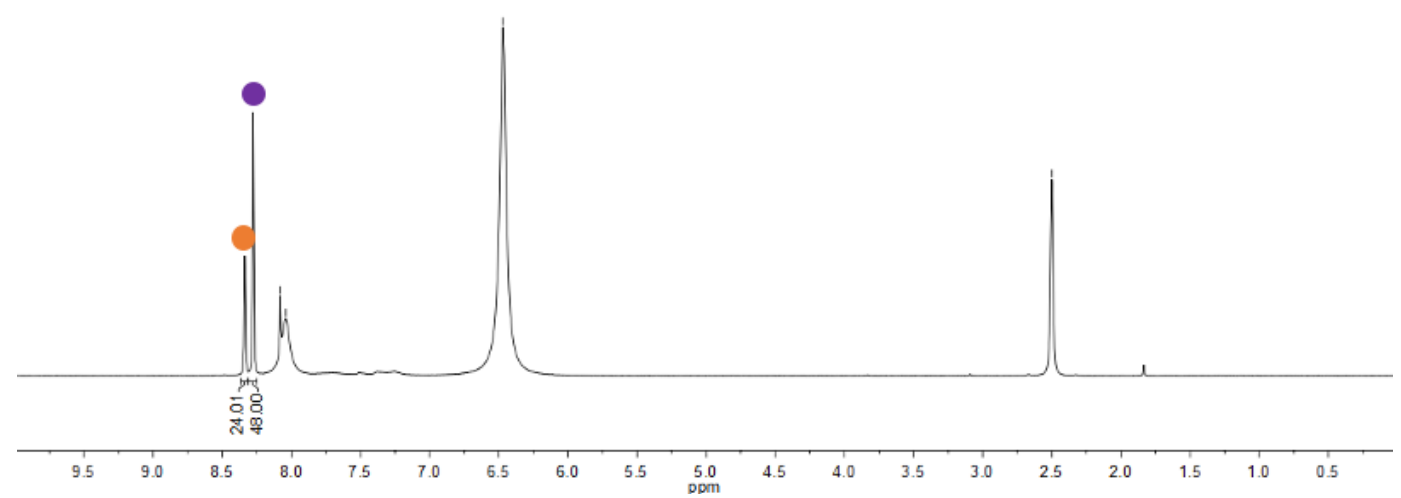

Figure $\mathbf{S 1 2}-{ }^{1} \mathrm{H}$ NMR analysis of digested $\mathrm{Cu} \_\mathrm{Li}$ in DMSO.

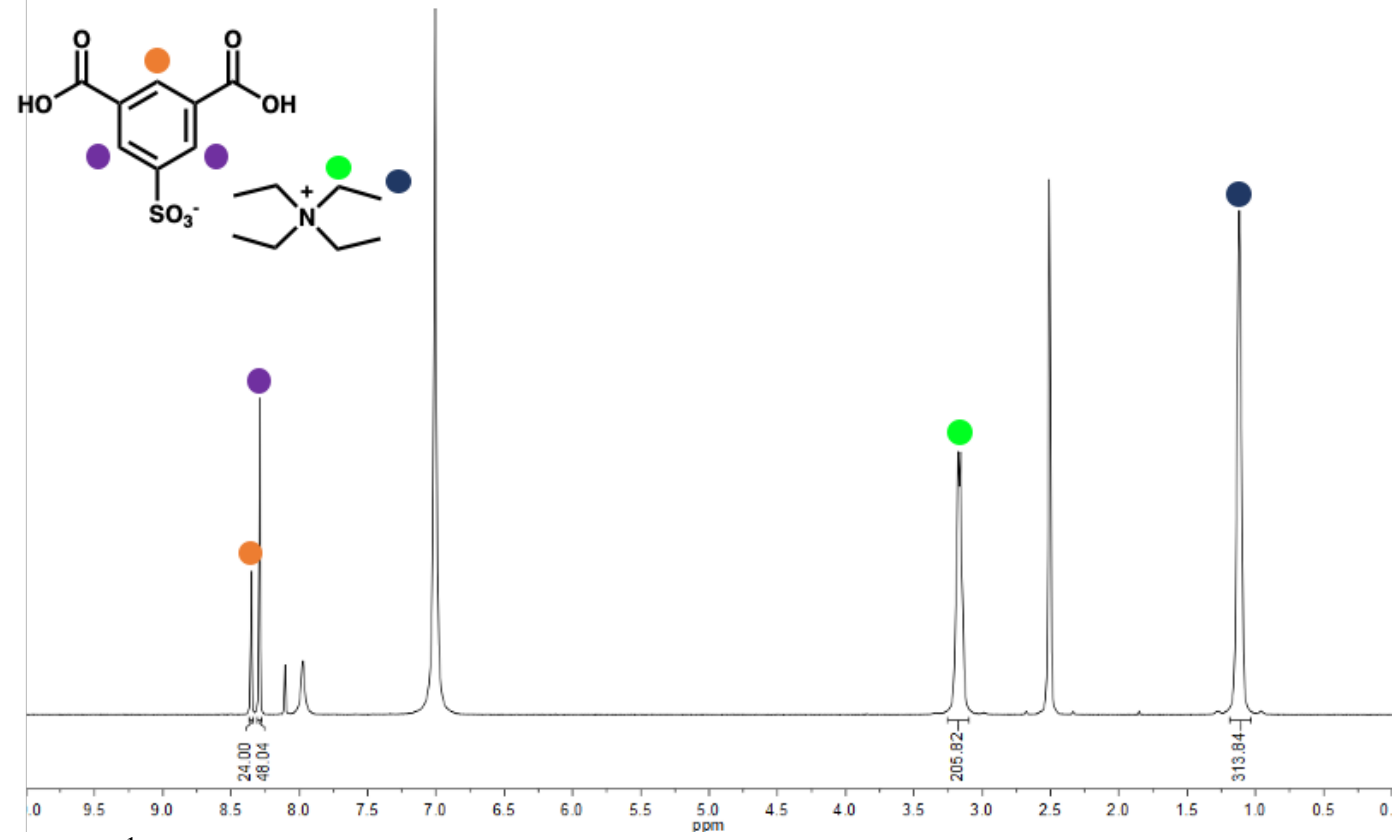

Figure S13 $-{ }^{1} \mathrm{H}$ NMR analysis of digested $\mathrm{Cu}_{-}$TEA in DMSO. 

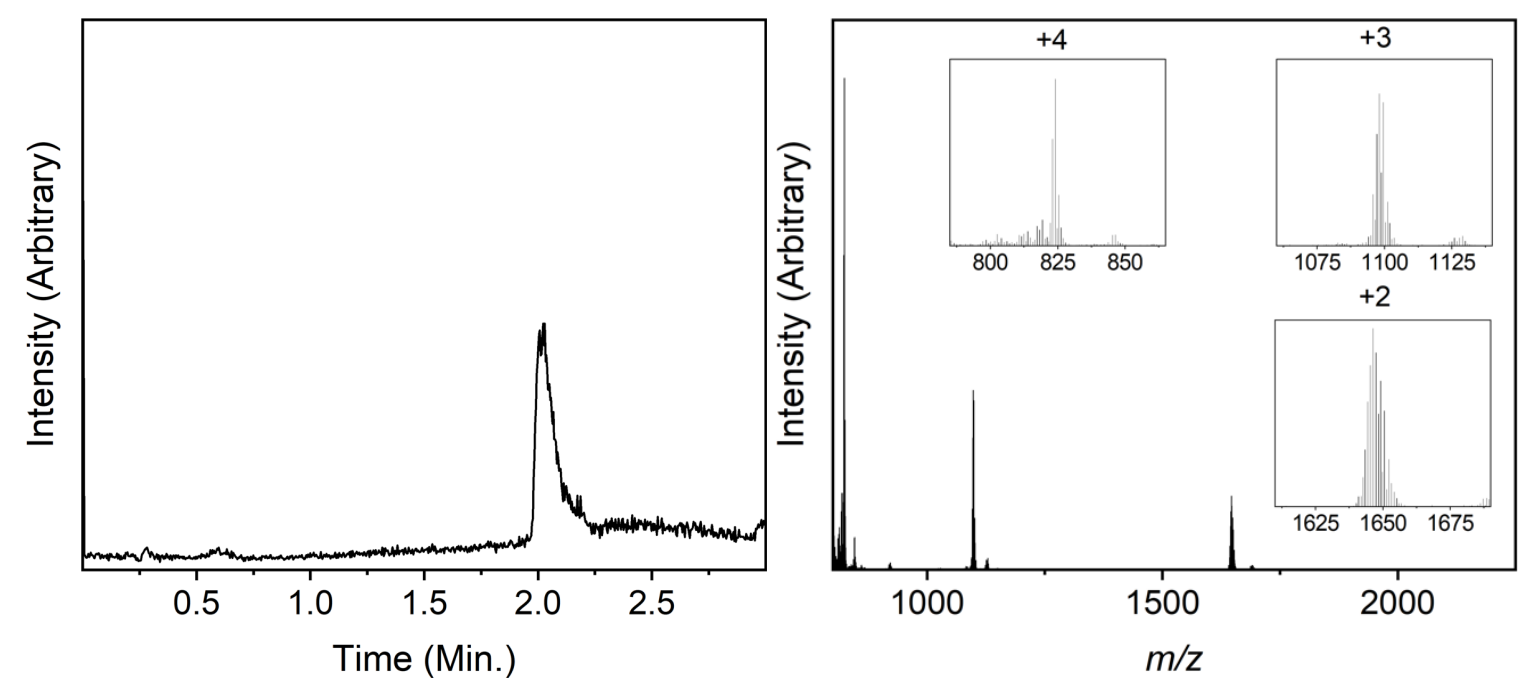

Figure S14 - (Left) Low-resolution ESI-mass spectrometry of $\mathrm{Zr}$ _Cl in methanol. (Right) Lowresolution ESI-mass spectrum of $\mathrm{Zr}_{-} \mathrm{Cl}_{4}$ in methanol. The presence of a $+4,+3$, and +2 peak indicates the phase is a tetrahedron.
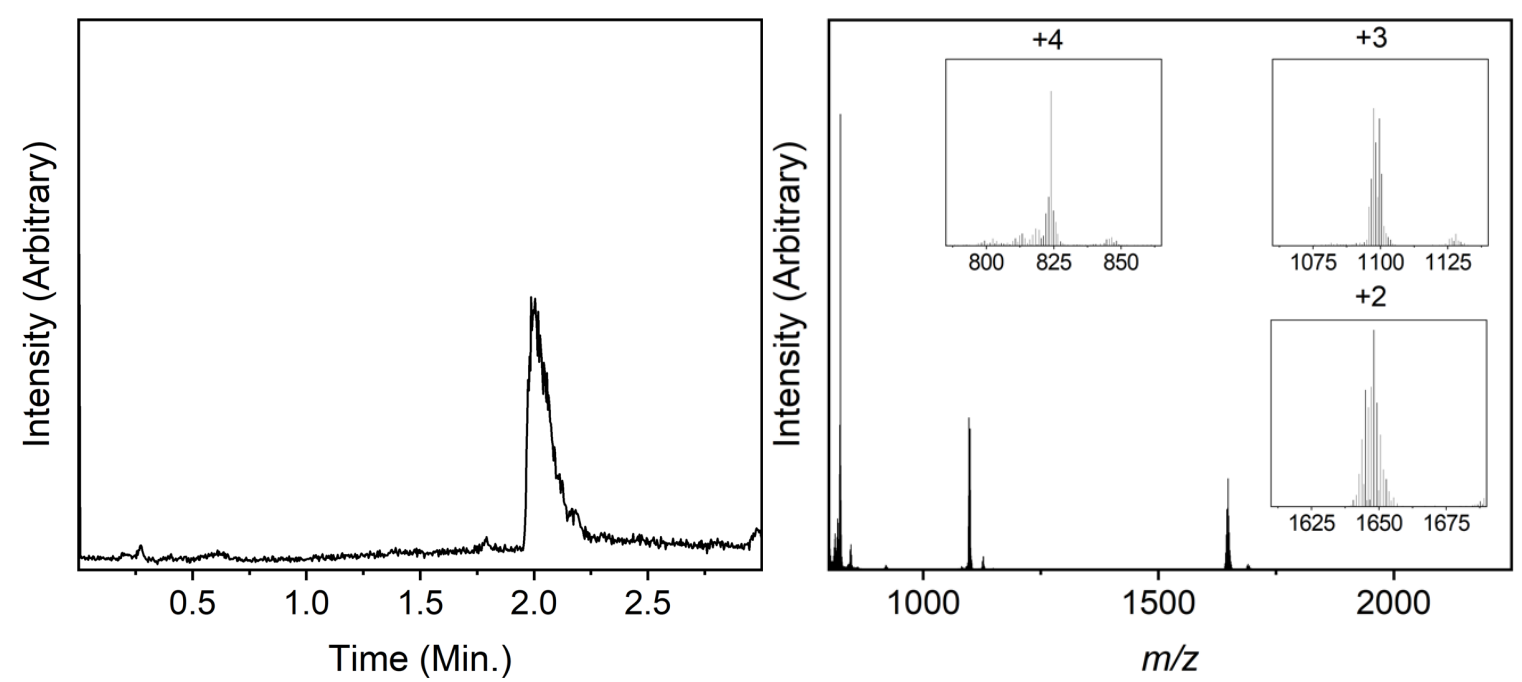

Figure S15 - (Left) Low-resolution ESI-mass spectrometry of Zr_OTf in methanol. (Right) Lowresolution ESI-mass spectrum of Zr_OTf in methanol. The presence of a $+4,+3$, and +2 peak indicates the phase is a tetrahedron. 

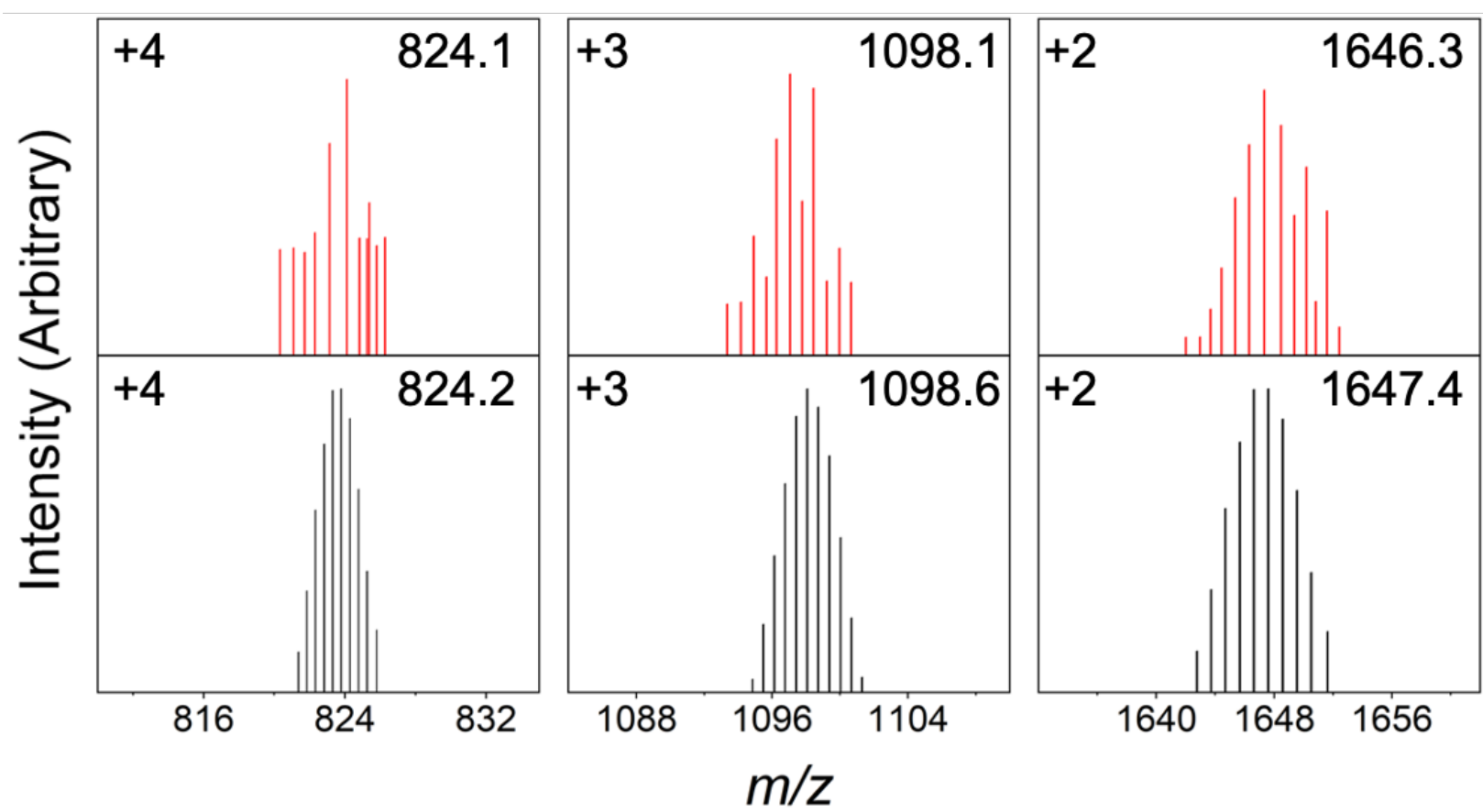

Figure S16 - Simulated (black) vs experimental (red) mass spectrum of $\mathrm{Zr} C \mathrm{Cl}$ in methanol.
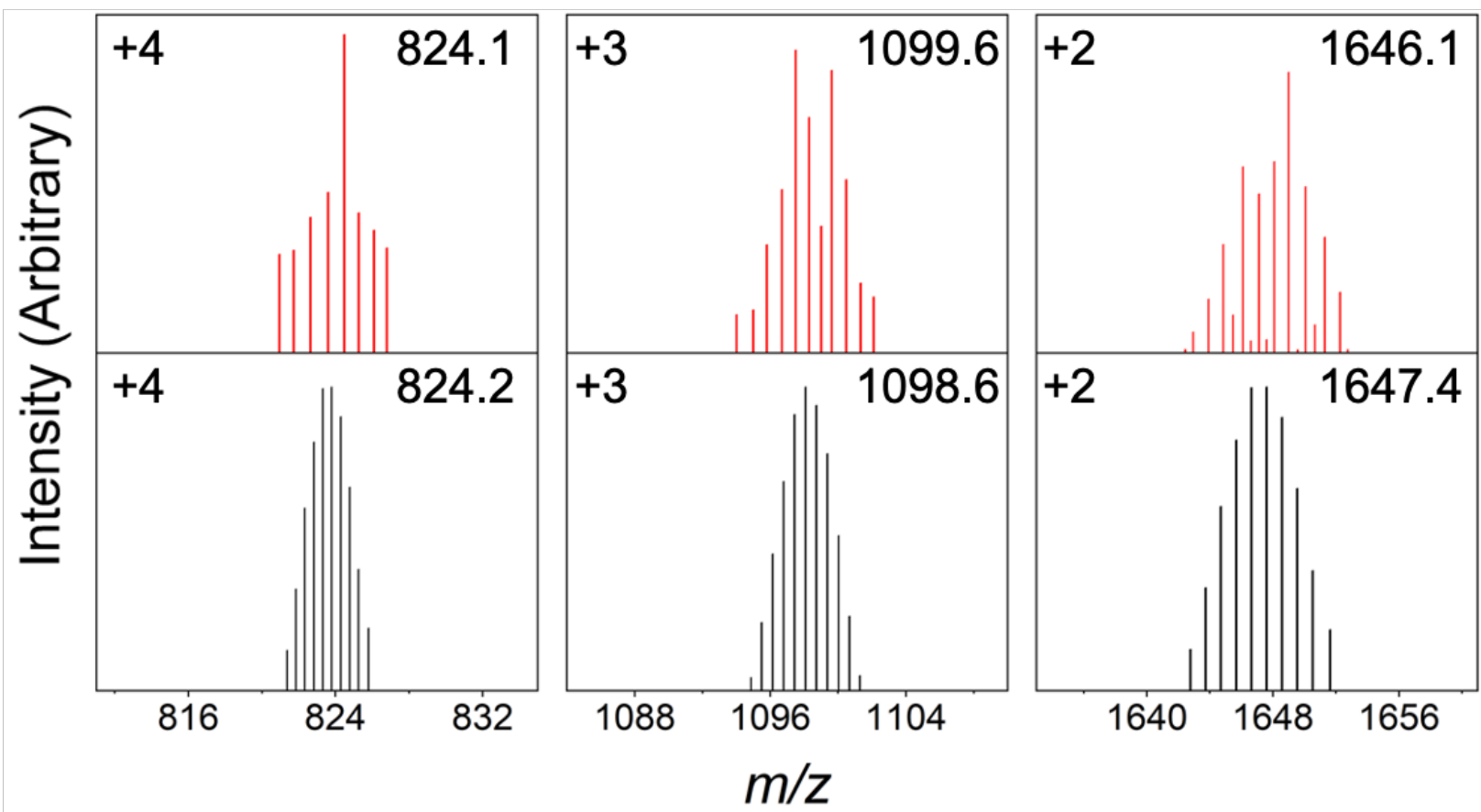

Figure S17 - Simulated (black) vs experimental (red) mass spectrum of Zr_OTf in methanol.

Species of $\mathrm{Zr} \mathrm{Cl}_{\mathrm{C}}$ and $\mathrm{Zr}$ OTf present in the mass spectrometry experiments.

$+4:\left[\mathrm{Zr}_{12}\left(\mu_{3}-\mathrm{O}\right)_{4}\left(\mu_{2}-\mathrm{OH}\right)_{12}(\mathrm{Cp})_{12}\left(\mathrm{Me}_{2}-\mathrm{bdc}\right)_{6}\right]^{4+}$

$+3:\left[\mathrm{Zr}_{12}\left(\mu_{3}-\mathrm{O}\right)_{4}\left(\mu_{2}-\mathrm{OH}\right)_{11}\left(\mu_{2}-\mathrm{O}\right)_{1}(\mathrm{Cp})_{12}\left(\mathrm{Me}_{2}-\mathrm{bdc}\right)_{6}\right]^{3+}$

$+2:\left[\mathrm{Zr}_{12}\left(\mu_{3}-\mathrm{O}\right)_{4}\left(\mu_{2}-\mathrm{OH}\right)_{10}\left(\mu_{2}-\mathrm{O}\right)_{2}(\mathrm{Cp})_{12}\left(\mathrm{Me}_{2}-\mathrm{bdc}\right)_{6}\right]^{2+}$ 

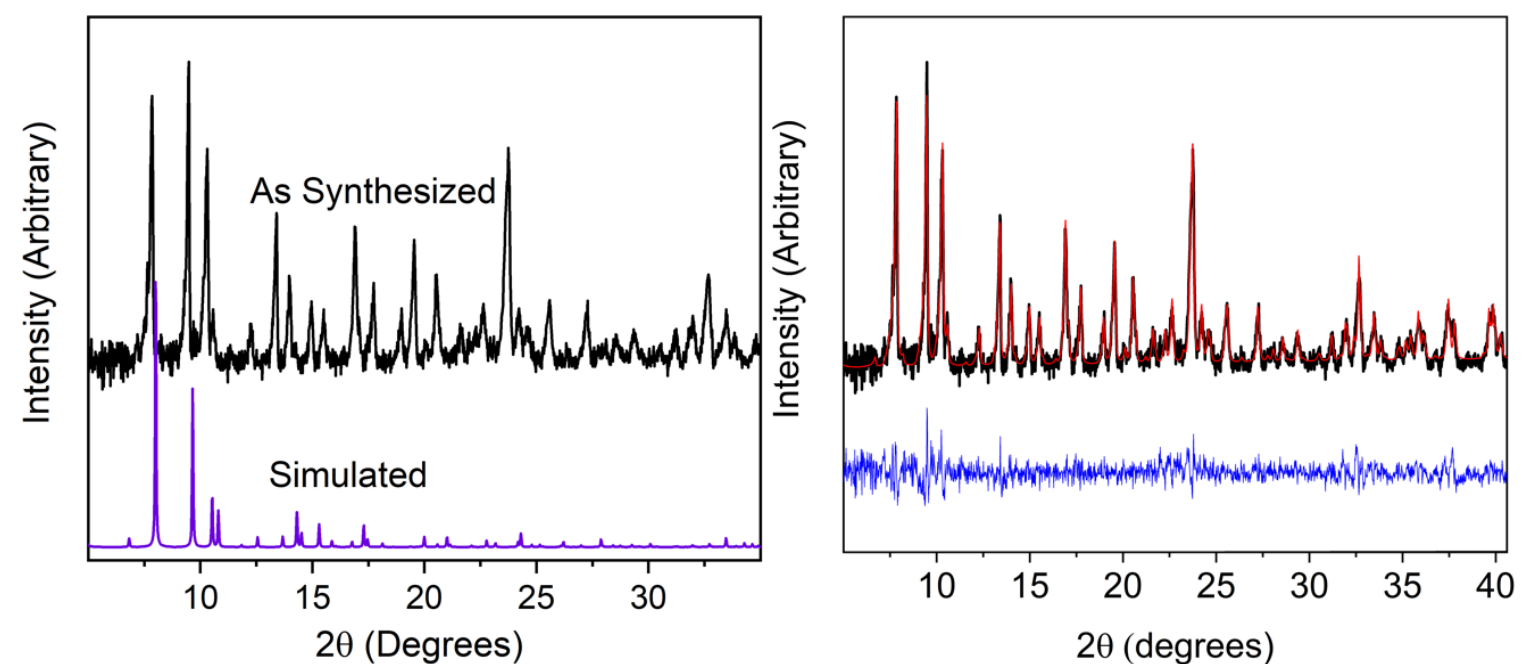

Figure S18 - (Left) Powder X-Ray diffraction pattern of Zr_Cl. (Right) Pawley refinement of Zr_Cl using space group Fm-3m (a=37.51 $\AA$; Rwp: 4.14) with experimental data (black), fit (red), and difference curve (blue). For comparison: Single-crystal data gave the space $F m-3 m(\mathrm{a}=36.59)$.
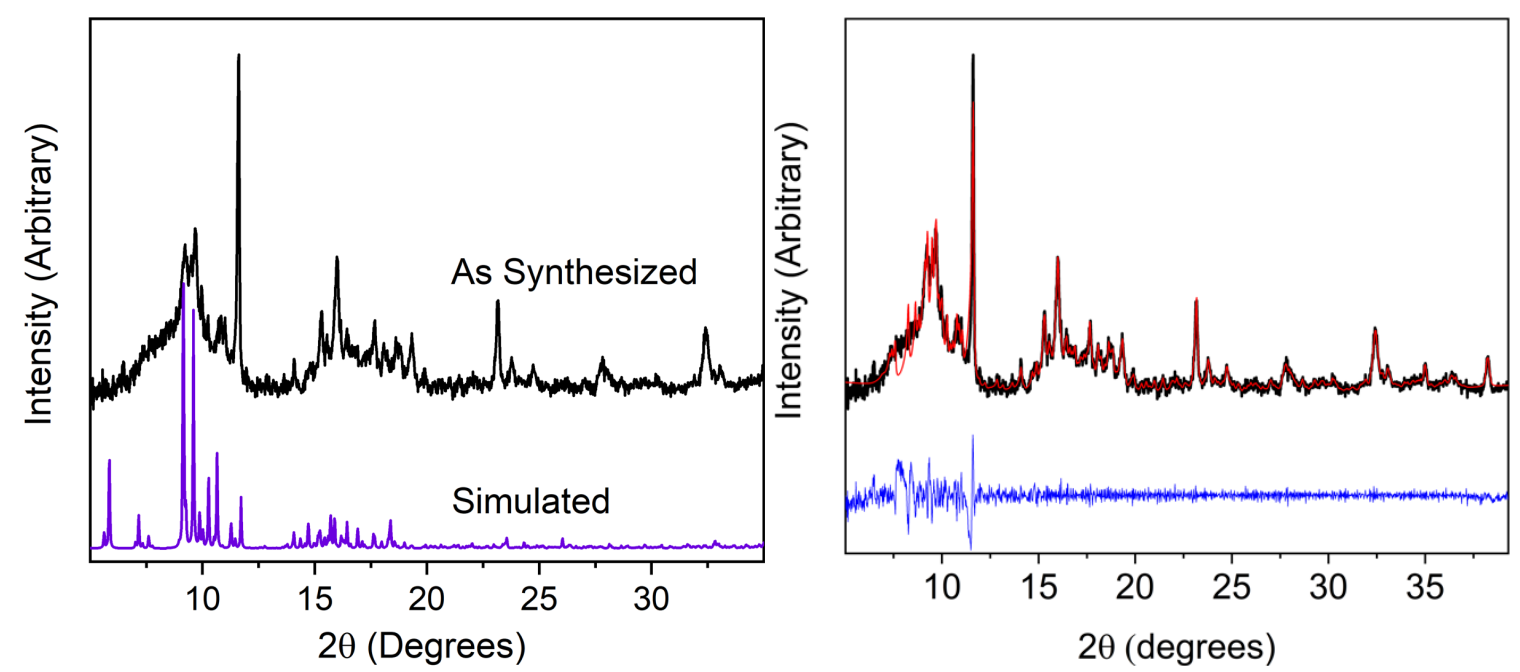

Figure S19 - (Left) Powder X-Ray diffraction pattern of Zr_OTf. (Right) Pawley refinement of $\mathrm{Zr} \_$OTf using space group $P 2_{1} / c(\mathrm{a}=34.67, \mathrm{~b}=17.08, \mathrm{c}=35.72 \AA \AA$; Rwp: 4.13) with experimental data (black), fit (red), and difference curve (blue). For comparison: Single-crystal data gave the space $P 2{ }_{1} / c(\mathrm{a}=35.29, \mathrm{~b}=17.21, \mathrm{c}=35.42)$. 

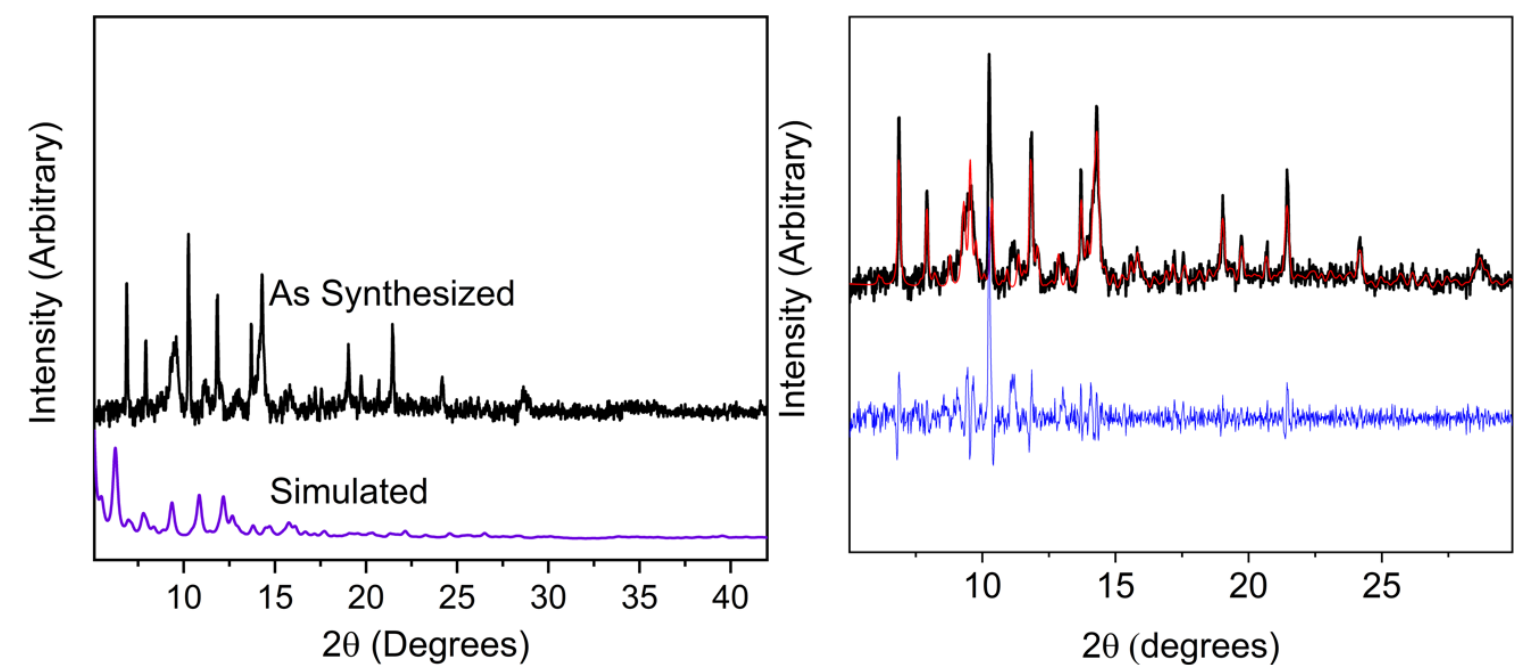

Figure S20 - (Left) Powder X-Ray diffraction pattern of $\mathrm{Cu}$ Li. (Right) Pawley refinement of $\mathrm{Cu}$ LLi using space group P4/mnc $(\mathrm{a}=35.85, \mathrm{~b}=35.85, \mathrm{c}=28.43 \AA$; Rwp: 48.43) with experimental data (black), fit (red), and difference curve (blue). For comparison: Single-crystal data gave the space $P 4 / m n c(\mathrm{a}=35.94, \mathrm{~b}=35.94, \mathrm{c}=28.29)$. 

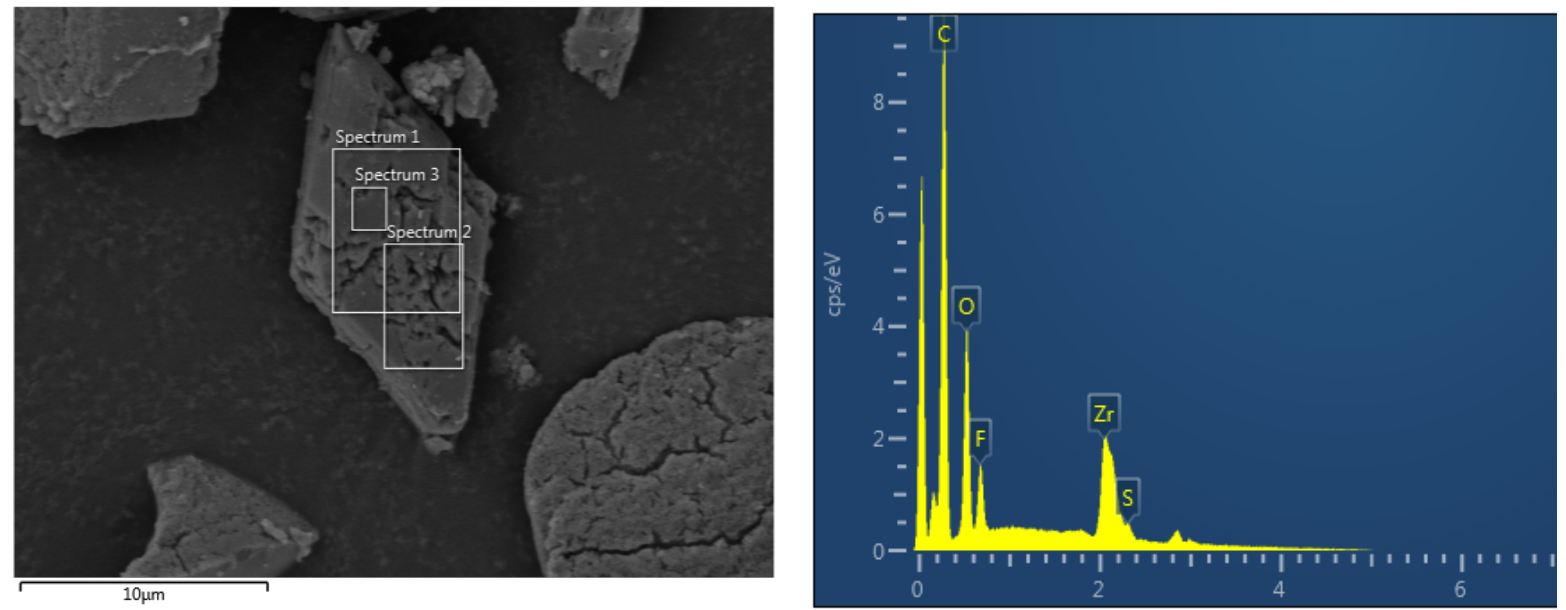

Figure S21 - (Left) Scanning Electron Microscope image of activated Zr_OTf. (Right) Energydispersive X-ray spectroscopy spectrum 1 of Zr_OTf.
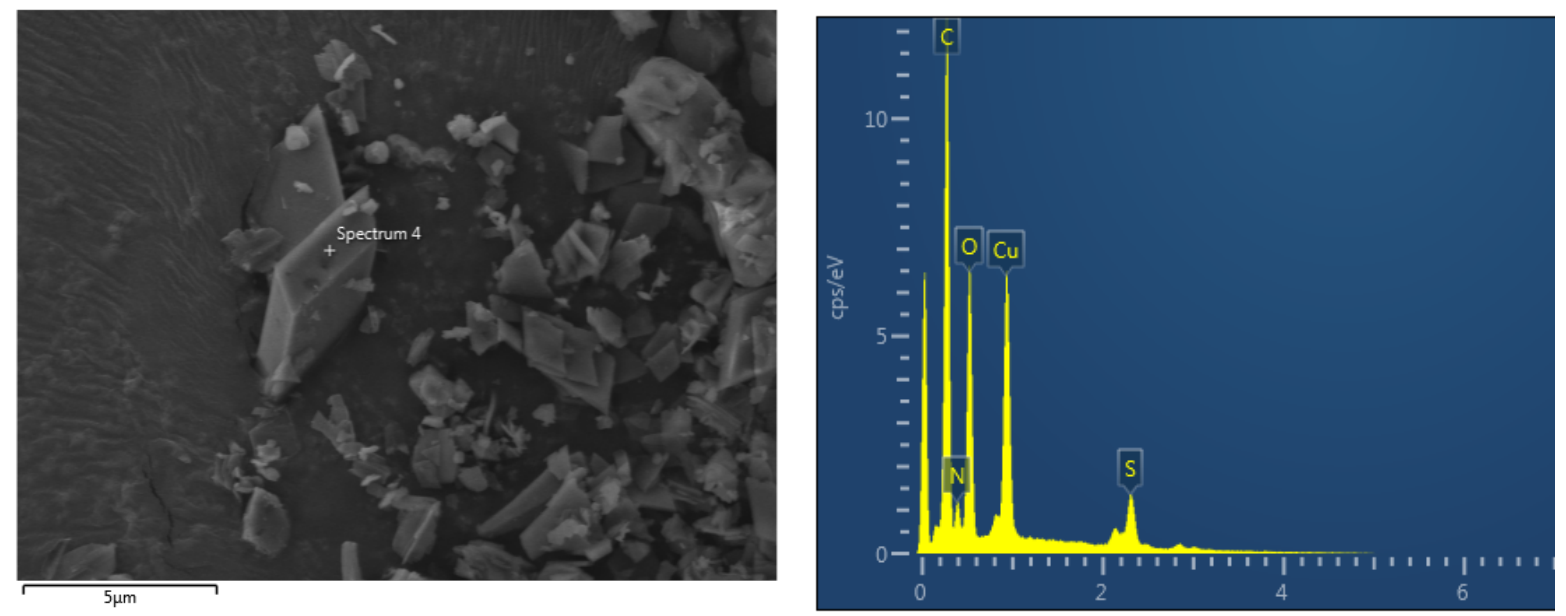

Figure S22 - Scanning Electron Microscope image of activated Cu_Li. (Right) Energy-dispersive X-ray spectroscopy spectrum 4 of $\mathrm{Cu}_{-} \mathrm{Li}$. 

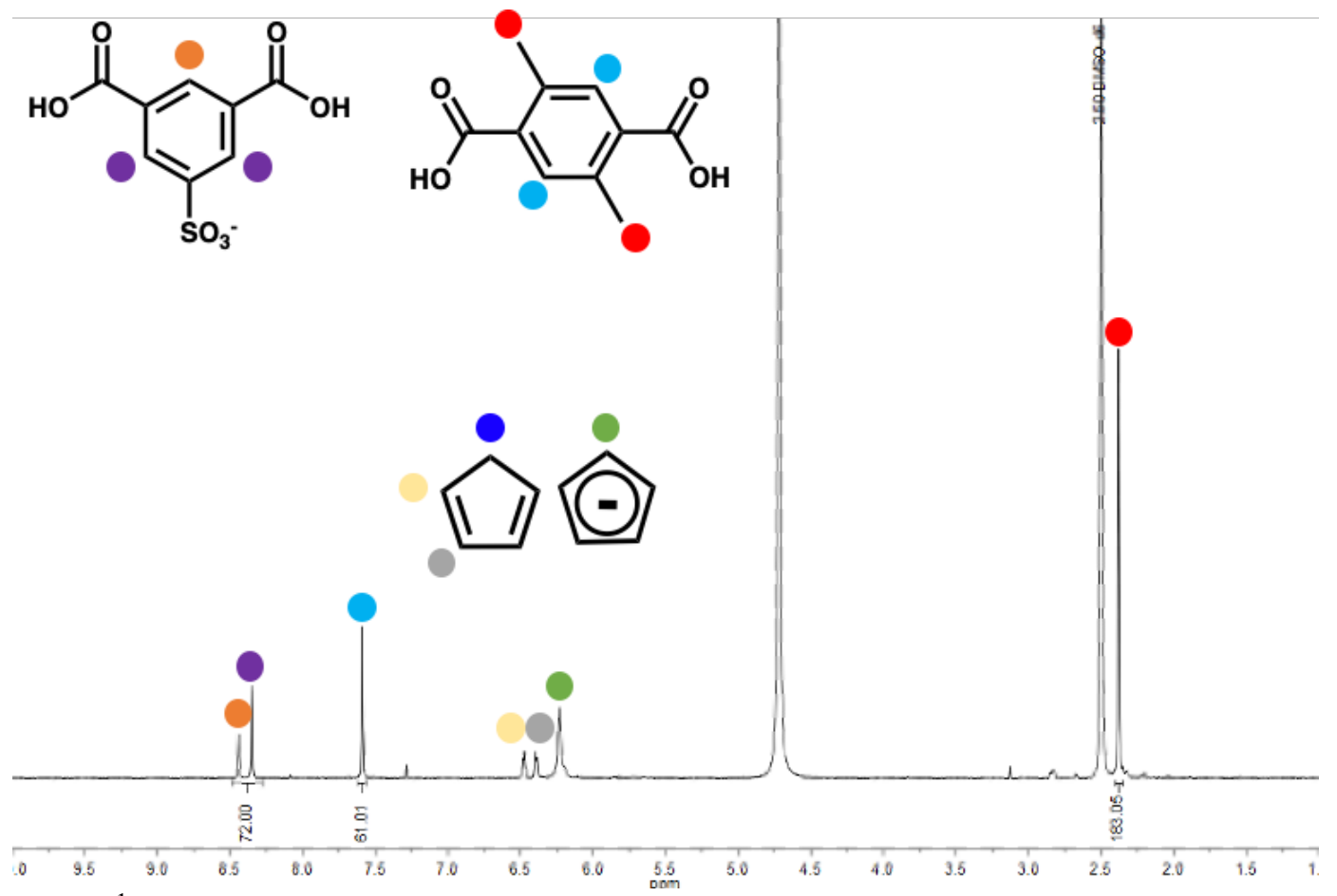

Figure S23 - ${ }^{1} \mathrm{H}$ NMR analysis of digested $\mathrm{Zr}-\mathrm{Cu}-150$ in DMSO.

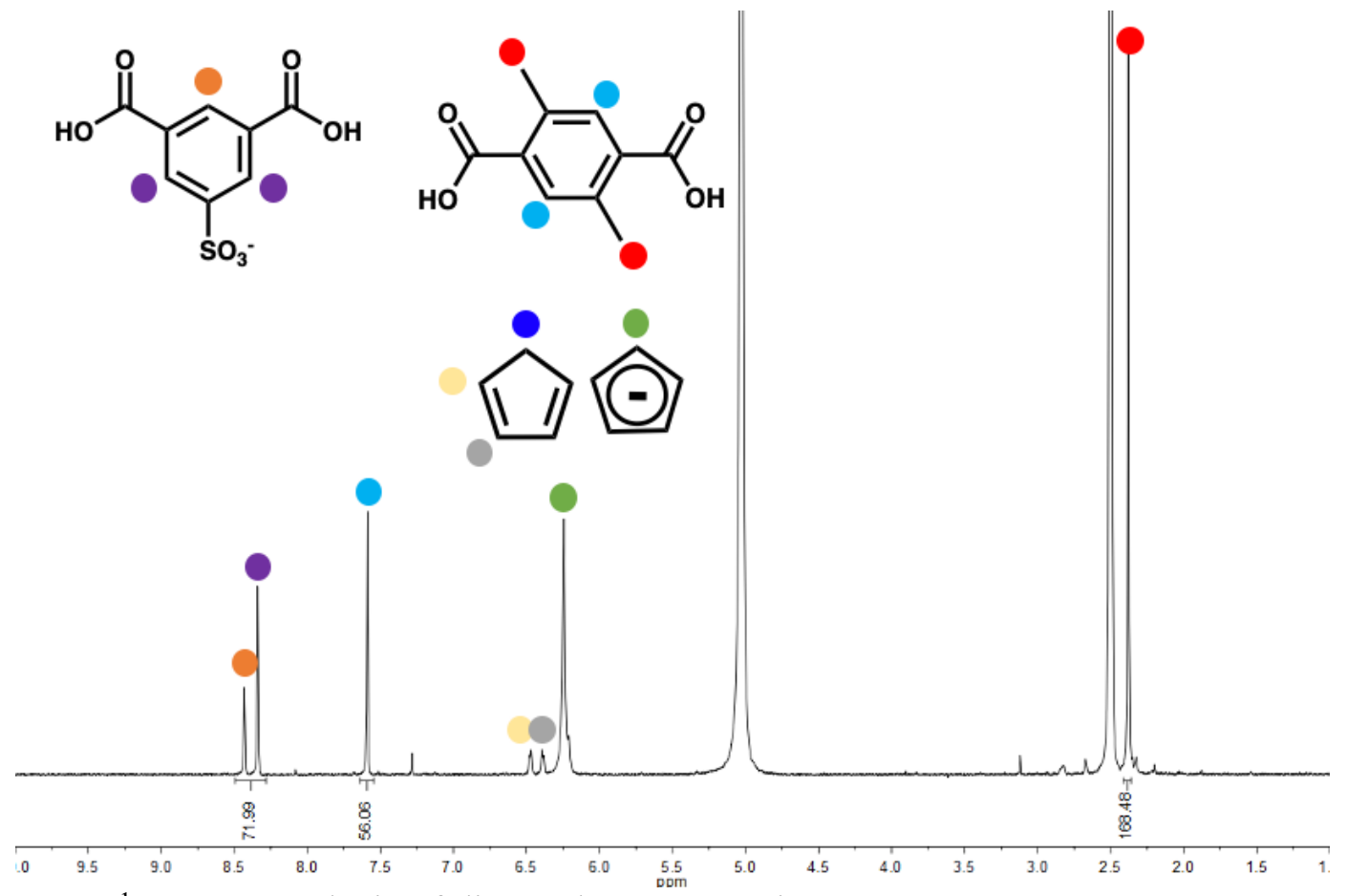

Figure S24 $-{ }^{1} \mathrm{H}$ NMR analysis of digested Zr-Cu-300 in DMSO. 
<smiles>O=C(O)c1cc(C(=O)O)cc([S+](=O)(=O)O)c1</smiles><smiles>O=C(O)c1cc(Cl)c(C(=O)O)cc1O</smiles>

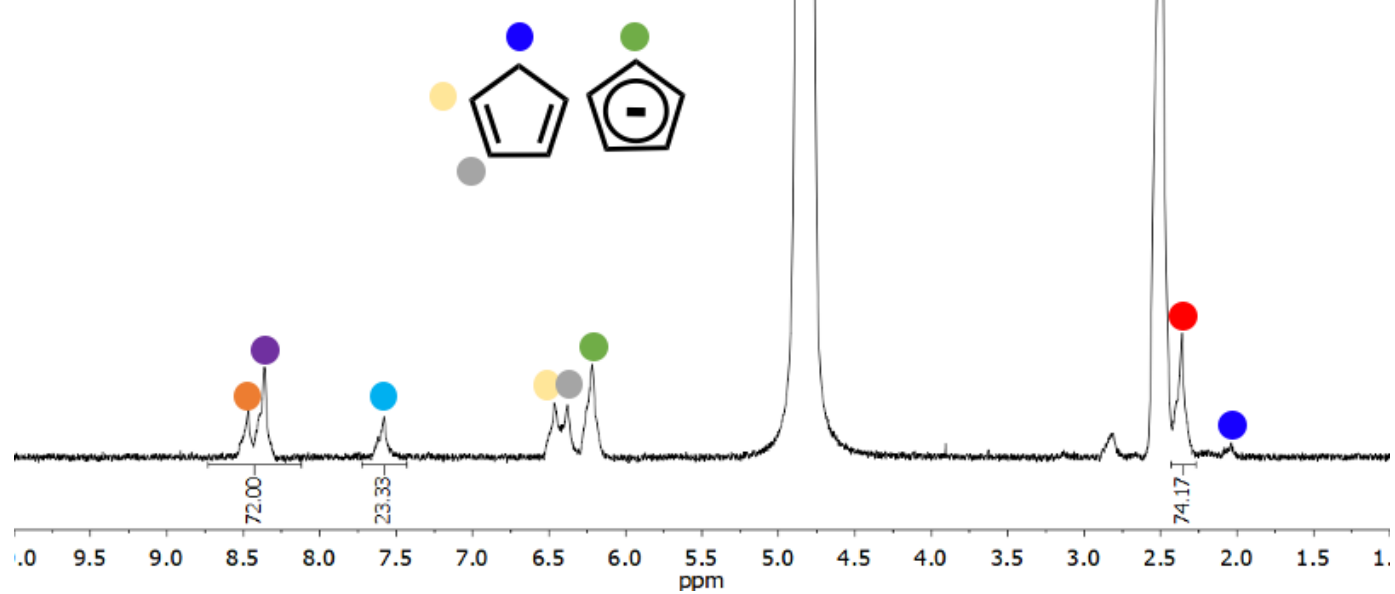

Figure S25 - ${ }^{1} \mathrm{H}$ NMR analysis of digested $\mathrm{Zr}-\mathrm{Cu}$ 2:1 anion: cation material in DMSO.<smiles>O=C(O)c1cc(C(=O)O)cc([N+](=O)[O-])c1</smiles><smiles>O=C(O)c1cc(Cl)c(C(=O)O)cc1O</smiles><smiles>OC1C=CC(C2CCCO2)=C1</smiles>

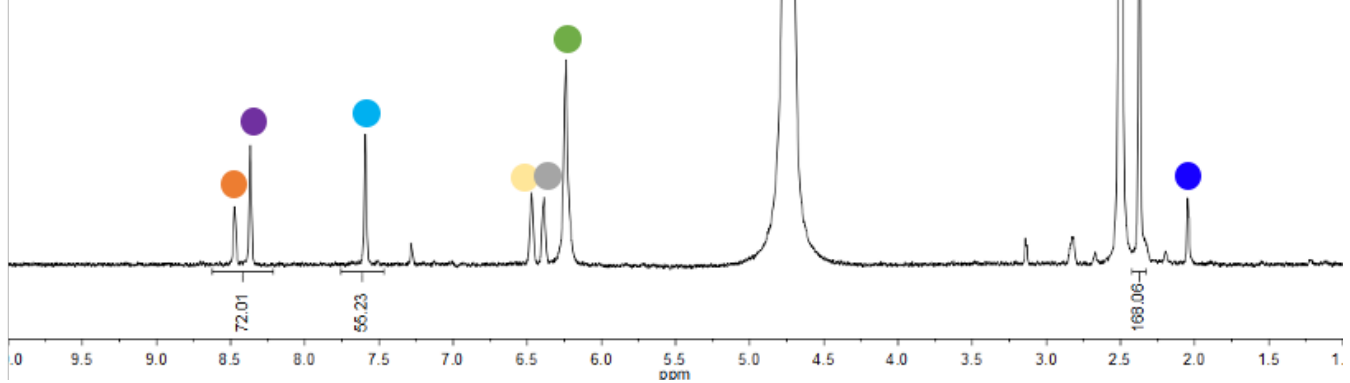

Figure S26 $-{ }^{1} \mathrm{H}$ NMR analysis of digested $\mathrm{Zr}-\mathrm{Cu}$ 1:2 anion: cation material in DMSO. 


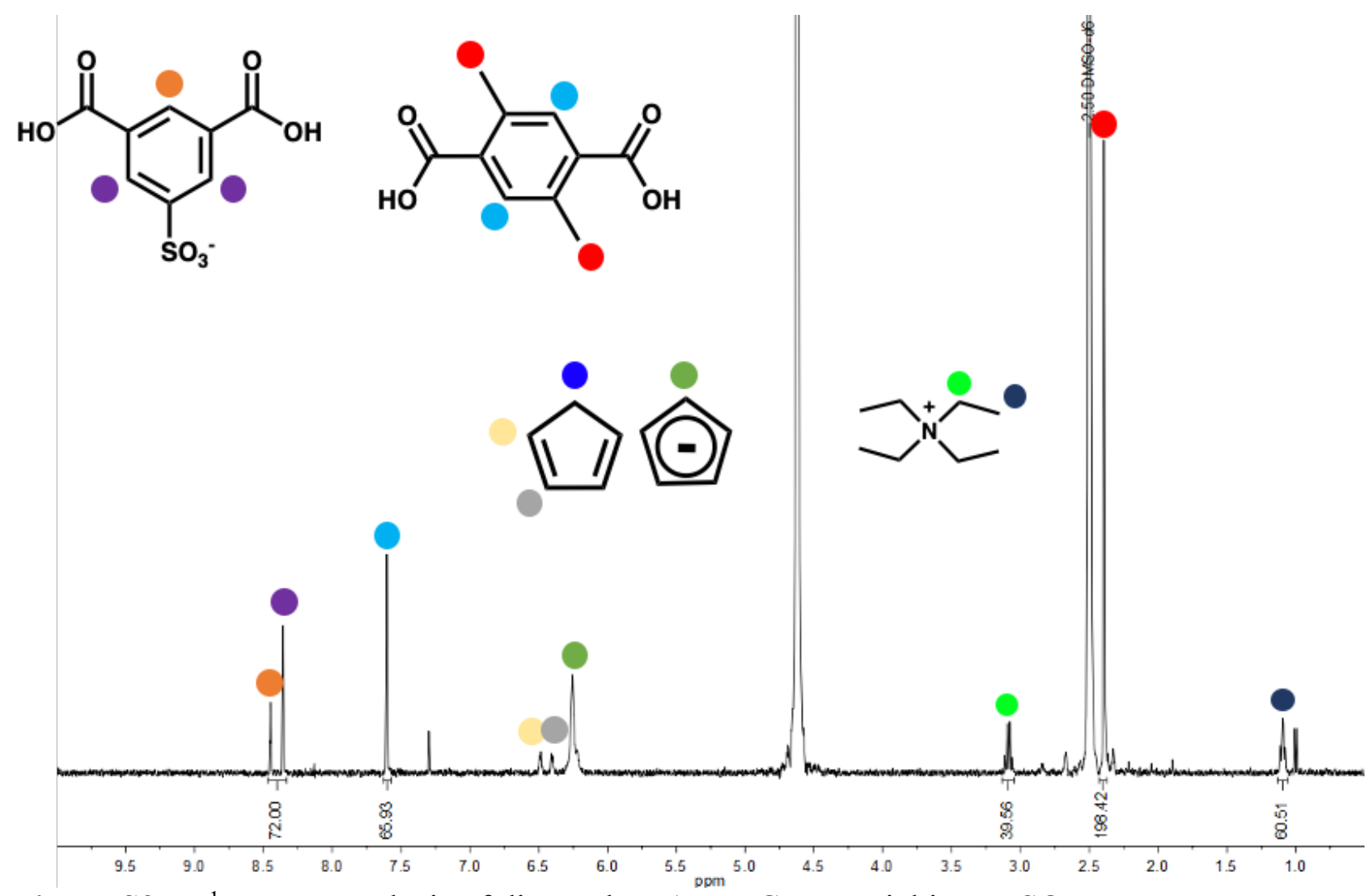

Figure S27 - ${ }^{1} \mathrm{H}$ NMR analysis of digested TEA ${ }_{16} \mathrm{Zr}-\mathrm{Cu}$ material in DMSO. 


\section{Single Crystal X-ray Diffraction}

$\mathrm{X}$-ray structural analysis for $\mathrm{X}_{16} \mathrm{Zr}$-Cu-cubic, $\mathrm{X}_{16} \mathrm{Zr}$-Cu-hexagonal, $\mathrm{Cu} \_\mathrm{Li}, \mathrm{Zr} \_\mathrm{Cl}$, and $\mathrm{Zr}$ OTf: Crystals were selected under polarized light, mounted using viscous oil onto a plastic mesh and cooled to the data collection temperature. Data were collected on a Bruker-AXS APEX II DUO $\mathrm{CCD}$ diffractometer with $\mathrm{Cu}-\mathrm{K} \alpha$ radiation $(\lambda=1.54178 \AA$ ) focused with Goebel mirrors. Unit cell parameters were obtained from 48 data frames, $0.5^{\circ} \omega$, from three different sections of the Ewald sphere. The unit-cell dimensions, equivalent reflections and systematic absences in the diffraction data are consistent with $P 312, P 31 \mathrm{~m}$, and $P-3 m 1$ for $\mathrm{X}_{16} \mathrm{Zr}-\mathrm{Cu}$-hexagonal; uniquely with $P 2_{1} / \mathrm{c}$ for Zr_OTf; with F432, F-43m and Fm-3m for $\mathrm{X}_{16} \mathrm{Zr}$-Cu-cubic and Zr_Cl; and, $P 4 n c$ and $P 4 / m n c$ for $\mathrm{Cu}_{\mathrm{C}}$ Li. Refinement in the centrosymmetric space group options yielded chemically reasonable and computationally stable results of refinement. The data were treated with multi-scan absorption corrections. $^{2}$ Structures were solved using intrinsic phasing methods ${ }^{3}$ and refined with full-matrix, least-squares procedures on $F^{2}{ }^{4}$

For $\mathrm{X}_{16} \mathrm{Zr}$-Cu-hexagonal, the $\mathrm{Cu} 24$ cluster is located at a three-fold rotoinversion axis while the $\mathrm{Zr} 12$ tetrahedra is at a three-fold rotation axis. The rotoinversion and rotation axes are parallel to mirror planes. The rotation axis site has twice the occupancy of the rotoinversion axis site thus there are two $\mathrm{Zr} 12$ clusters per $\mathrm{Cu} 24$ cluster. One symmetry-unique $\mathrm{SO}_{3}$ moiety was located disordered in two positions, treated with averaged O...O and C...O interatomic distances, and averaged S-O bond distances, and with equal atomic displacement constraints between chemically equivalent atoms in each disordered contribution, with a refined site occupancy ratio of 56/44. A dimethyl phenyl group was found disordered by a mirror plane with assigned 50/50 site occupancy contribution. The disordered dimethyl phenyl group was treated with idealized geometrical restraints.

For $\mathrm{Zr}$-Cl the compound molecule is located at a four-fold rotoinversion axis, three-fold rotation axis and a mirror plane. The $\mathrm{Cu}$ cluster and the $\mathrm{Zr}$ tetrahedron in $\mathrm{X}_{16} \mathrm{Zr}$-Cu-cubic is each located at two perpendicular mirrors and a three-fold rotoinversion axis and in the case of the $\mathrm{Zr}$ tetrahedron is disordered by crystallographic site symmetry higher than its molecular symmetry. The compound molecule in $\mathrm{Li}_{24}\left[\mathrm{Cu}_{24}\left(\mathrm{SO}_{3} \text {-bdc }\right)_{24}\right]$ is located at a four-fold axis and a mirror.

Two $p$-dimethylphenyl moieties in Zr_OTf were each found in two disordered positions with refined site occupancy ratios of 57/43 and 52/48. Three sulfonate groups and one DMA solvent in $\mathrm{Cu} \_$Li were found to be disordered with refined site occupancies of 56/44,73/27, 54/46, and 52/48, respectively.

Global three-dimensional rigid bond restraints on anisotropic displacement parameters were applied on. non-hydrogen atoms that were refined with anisotropic displacement parameters. Global rigid bond restraints were imposed on displacement parameters for $\mathrm{Zr} \_\mathrm{Cl}$ and $\mathrm{X}_{16} \mathrm{Zr}-\mathrm{Cu}-$ cubic which were refined isotropically to conserve a reasonable data to parameter ratio. Hydrogen atoms were treated as idealized contributions with geometrically calculated positions and with $U_{\text {iso }}$ equal to $1.2 U_{e q}\left(1.5 U_{e q}\right.$ for methyl) of the attached atom. Residual electron density located away the identified chemical species were treated as diffused contributions using Squeeze. ${ }^{5}$ Atomic scattering factors are contained in the SHELXTL program library. ${ }^{4}$ The CIFs have been deposited at the Cambridge Structural Database under CCDC 1955208 ([Zr_Cl), 1955219 (Zr_OTf), 1976851 (X $\mathrm{X}_{16} \mathrm{Zr}-\mathrm{Cu}$-hexagonal), 1988667 (X16 Zr-Cu-cubic) and 1988668 (Cu_Li). 
Table 1. Table displaying the surface areas of select copper and zirconium-based coordination cages.

\begin{tabular}{|c|c|c|c|}
\hline Cage & BET $\left(\mathbf{m}^{2} / \mathbf{g}\right)$ & Langmuir $\left(\mathbf{m}^{2} / \mathbf{g}\right)$ & Ref \\
\hline $\mathrm{Cu}_{24}(\mathrm{tei})_{24}$ & 739 & 843 & 6 \\
\hline $\mathrm{Cu}_{24}(\mathrm{OEt}-\mathrm{bdc})_{24}$ & 545 & 727 & 7 \\
\hline $\mathrm{Cu}_{24}\left(\mathrm{SO}_{3}-\mathrm{bdc}\right) \mathrm{Na}_{16} \mathrm{H}_{8}$ & 7 & - & 8 \\
\hline$\left[\mathrm{Zr}_{12}\left(\mu_{3}-\mathrm{O}\right)_{4}\left(\mu_{2}-\mathrm{OH}\right)_{12}(\mathrm{Cp})_{12}\left(\mathrm{NH}_{2}-\mathrm{bdc}\right)_{6}\right] \mathrm{Cl}_{4}$ & 782 & 900 & 9 \\
\hline$\left[\mathrm{Zr}_{12}\left(\mu_{3}-\mathrm{O}\right)_{4}\left(\mu_{2}-\mathrm{OH}\right)_{12}(\mathrm{Cp})_{12}(\mathrm{bpdc})_{6}\right] \mathrm{Cl}_{4}$ & 729 & 930 & 10 \\
\hline$\left[\mathrm{Zr}_{12}\left(\mu_{3}-\mathrm{O}\right)_{4}\left(\mu_{2}-\mathrm{OH}\right)_{12}(\mathrm{Cp})_{12}(\mathrm{Mn} / \mathrm{Fe}-\mathrm{L})_{6}\right] \mathrm{Cl}_{4}{ }^{*}$ & 104 & - & 11 \\
\hline
\end{tabular}

*L = 1,2-cyclohexanediamine-N,N'-bis(3-tBu-5-(carboxyl)alicylide

\section{References}

(1) Huang, X.; Yang, L.; Berquist, J.; Strømme, M.; Gogoll, A.; Sjödin, M. Synthesis and Redox Properties of Thiophene Terephthalate Building Blocks for Low-Potential Conducting Redox Polymers. J. Phys. Chem. C. 2015, 119, $27247-27254$.

(2) Apex3; Bruker AXS Inc.: Madison, WI, 2015.

(3) Sheldrick, G. M. SHELXT - Integrated space-group and crystal-structure determination. Acta Cryst. 2015, A71, 3-8.

(4) Sheldrick, G. M. Crystal structure refinement with SHELXL. Acta Cryst. 2015, C71, 3-8.

(5) Spek, A. L. PLATON SQUEEZE: a tool for the calculation of the disordered solvent contribution to the calculated structure factors. Acta Cryst. 2015, C71, 9-18.

(6) Liu, T.-F.; Chen, Y.-P.; Yakovenko, A. A.; Zhou, H.-C. Interconversion between Discrete and a Chain of Nanocages: Self-Assembly via a Solvent-Driven, Dimension-Augmentation Strategy. J. Am. Chem. Soc. 2012, 134, 17358-17361.

(7) Barreda, O.; Bannwart, G.; Yap, G. P. A.; Bloch, E. D. Ligand-Based Phase Control in Porous Molecular Assemblies. ACS Appl. Mater. Interfaces 2018, 10, 11420-11424.

(8) Sun, L.-B.; Li, J.-R.; Lu, W.; Gu, Z.-Y.; Luo, Z.; Zhou, H.-C. Confinement of Metal-Organic Polyhedra in Silica Nanopores. J. Am. Chem. Soc. 2012, 134, 15923-15928.

(9) Nam, D.; Huh, J.; Lee, J.; Kwak, J. H.; Jeong, H. Y.; Choi, K.; Choe, W. Cross-Linking ZrBased Metal-Organic Polyhedra via Postsynthetic Polymerization. Chem. Sci. 2017, 8, 77657771.

(10) Liu, G.; Ju, Z.; Yuan, D.; Hong, M. In Situ Construction of a Coordination Zirconocene Tetrahedron. Inorg. Chem. 2013, 52, 13815-13817.

(11) Jiao, J.; Tan, C.; Li, Z.; Liu, Y.; Han, X.; Cui, Y. Design and Assembly of Chiral Coordination Cages for Asymmetric Sequential Reactions. J. Am. Chem. Soc. 2018, 140, 2251-2259. 